\title{
Kristine Azarjana
}

\section{MELANOMA \\ PROGNOSTIC AND \\ RISK FACTORS}

\section{Summary of Doctoral Thesis for obtaining a degree of a Doctor of Medicine Speciality - Medicine}

Riga, 2012 


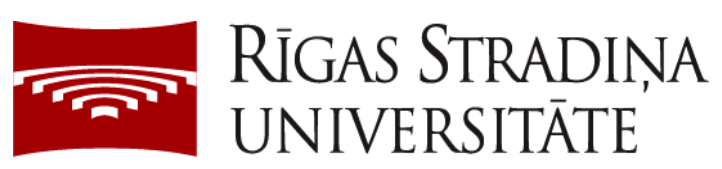

Kristīne Azarjana

\section{Melanoma prognostic and risk factors}

Summary of Doctoral Thesis

Speciality - medicine

Riga, 2012 
The present Doctoral study has been conducted at the Latvian Biomedical Research and Study Centre in collaboration with the Riga East University Hospital Latvian Oncology Centre. It has been approved by the Central Ethics Committee of Latvia.

\section{Scientific supervisors:}

Dr. habil. med. Prof. Ingrīda Čēma, RSU

Dr. biol. Dace Pjanova, Latvian Biomedical Research and Study Centre

\section{Approved reviewers:}

Dr. med. Rūta Brūvere, Latvian Biomedical Research and Study Centre

Dr. biol. assoc. Prof. Edvīns Miklašēvičs, RSU

Dr. med. Prof. Wilma Berman, Leiden University

Presentation of the Doctoral thesis will take place on November 12th, 2012 at 16.00 o'clock during an open meeting of the Promotional Council meeting in Fundamental Sciences at Hippocrates auditorium, Riga Stradin's University, Dzirciema Street 16, Riga.

The Doctoral thesis is available at the RSU library and on the RSU web page: www.rsu.lv

The doctoral study has been conducted with the financial support of the:

- European Social Fund project "Support for Doctoral Students in Acquiring Study Programme and Acquisition of the Scientific Degree in Riga Stradin's University", Nr.2009/0147/1DP/1.1.2.1.2/09/IPIA/VIAA/009;

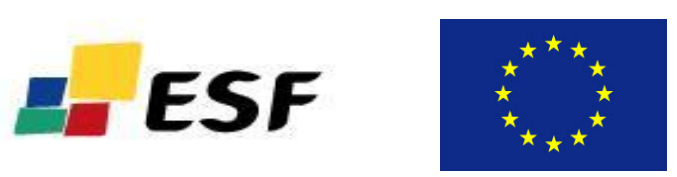

- FP6 projekts: GenoMEL-018702 „Genetic and environmental determinants of melanoma: translation into behavioural change";

- European Economic Area Financial Mechanism block grant Nr. EEZ09AP-38 "The molecular genetic alterations in the development of cutaneous malignant melanoma in Latvia".

Secretary of Doctoral Council:

Dr. habil. med. prof. Līga Āberberga-Augškalne 


\section{CONTENT}

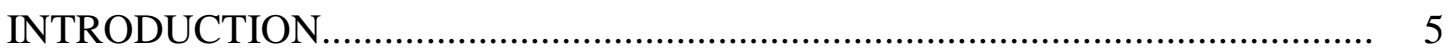

1. THE AIM, TASKS AND HYPOTHESIS OF THE STUDY ............................ 6

2. SCIENTIFIC NOVELTY AND PRACTICAL VALUE OF THE STUDY........ 7

3. MATERIAL AND METHODS................................................................ 8

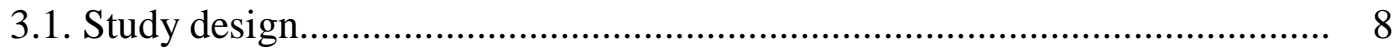

3.2. Analysis of epidemiological, clinical and histology data of melanoma

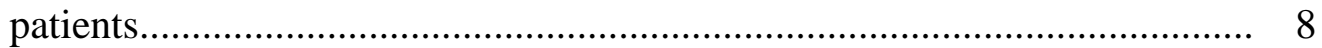

3.3. Genetic analysis of melanoma patients ..................................................... 9

3.3.1. Analysis of high-risk melanoma susceptibility genes $C D K N 2 A$

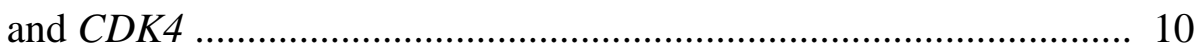

3.3.2. Analysis of low-risk melanoma susceptibility gene $M C 1 R \ldots \ldots \ldots \ldots 11$

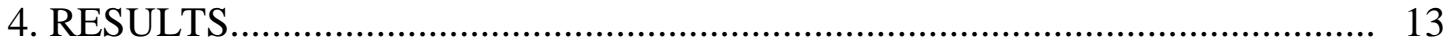

4.1. The epidemiology of melanoma................................................................ 13

4.2. Genetic changes in melanoma patients................................................... 19

4.2.1. Characteristics of patients enrolled in the genetic analysis ........... 19

4.2.2. Mutations in high-risk melanoma susceptibility genes $C D K N 2 A$ and $C D K 4$ in patients with family history of cancer....................... 20

4.2.3. Changes in gene $C D K N 2 A$ promoter and introns in patients with a family history of recurrent tumors ....................................... 27

4.2.4. Deletions in $C D K N 2 A$ region in patients with a family history of recurrent tumors.

4.2.5. Mutations in high-risk melanoma susceptibility genes $C D K N 2 A$ and $C D K 4$ in patients with multiple primary melanomas

4.2.6. Mutations in high-risk melanoma susceptibility genes $C D K N 2 A$ and $C D K 4$ in younger melanoma patients ( $\leq 40$ years).

4.2.7. The role of gene $M C 1 R$ polymorphisms in melanoma

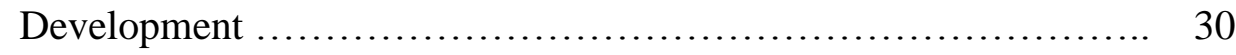

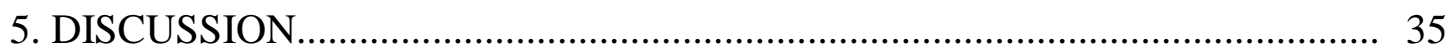

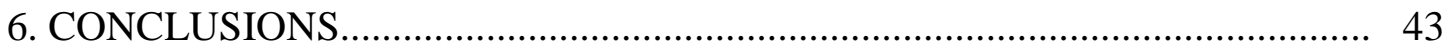

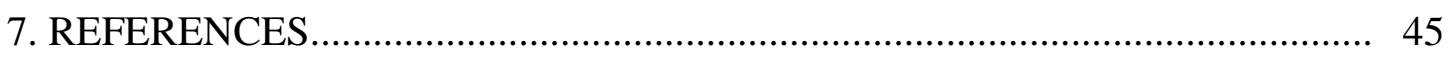

8. SCIENTIFIC PUBLICATIONS............................................................ 51

9. PRESENTATIONS OF THE STUDY RESULTS......................................... 52 


\section{ABBREVIATIONS}

$\begin{array}{ll}\text { cen } & \text { centromere } \\ \text { CI } & \text { confidence interval } \\ \text { CDK4 } & \text { cyclin-dependent kinase 4 gene } \\ \text { CDKN2A } & \text { cyclin-dependent kinase inhibitor 2A gene } \\ \text { CMM } & \text { cutaneous malignant melanoma } \\ \text { CNS } & \text { central nervous system } \\ \text { DNA } & \text { deoxyribonucleic acid } \\ \text { MC1R, MC1R } & \text { melanocortin 1 receptor, melanocortin 1 receptor gene } \\ \text { MLPA } & \text { multiplex ligation-dependent probe amplification } \\ \text { na } & \text { not analysed } \\ \text { nd } & \text { no data } \\ \text { NRHC } & \text { non red hair colour } \\ \text { OR } & \text { odds ratio } \\ \text { HR } & \text { hazard ratio } \\ \text { p } & \text { statistical significance } \\ \text { PCR } & \text { polymerase chain reaction } \\ \text { RHC } & \text { red hair colour } \\ \text { RAKUS LOC } & \text { Riga East University Hospital Latvian Oncology Centre } \\ \text { SD } & \text { standart deviation } \\ \text { SNP } & \text { single nucleotide polymorphism } \\ \text { SSM } & \text { superficial spreading melanoma } \\ \text { tel } & \text { telomere } \\ \text { UV } & \text { wiltraviolet radiation type } \\ \text { WT } & \\ & \end{array}$




\section{INTRODUCTION}

Cutaneous malignant melanoma (CMM) is the most malignant of all skin cancers which develops through pathological proliferation of melanocytes. Its global prevalence and mortality indicators increase year by year at a rate faster than for any other type of cancer. CMM is multifactor disease, caused by interaction of genes, the individual's pigmentation phenotype and environmental factors. The main external environmental risk factor for CMM is UV radiation and related sunburn, which is especially dangerous in childhood and in the teens. The most significant phenotypic risk factor is a large number of nevi, as well as atypical moles. Other phenotypic risk factors include lentigo, fair skin colour and red or blonde hair. As concerns genes and heredity, approximately $10 \%$ of CMM patients have a family history of recurring cases of the disease, pointing to its hereditary character. Melanoma is inherited as an autosomal dominant trait with incomplete penetrance, and two high-risk melanoma susceptibility genes - CDKN2A (cyclin-dependent kinase inhibitor 2A) and CDK4 (cyclin-dependent kinase 4) are known to exist. In the majority of families mutations* have been identified in the $C D K N 2 A$ gene. On the other hand, mutations in the $C D K 4$ gene are rare and have been identified only in separate families on a global scale. However, mutations in the abovementioned genes are not found in all families with recurrent melanoma. This leads to believe that there may be other yet unidentified high-risk melanoma susceptibility genes. Moreover, apart from the high-risk melanoma susceptibility genes, there are also genes conferring lower risk, with more frequent variations, which, however, are associated with a significantly lower risk of disease. Until now, only a single significant low-risk melanoma susceptibility gene has been identified, i.e. $M C 1 R$, accounting for particular hair colour, skin type, and melanoma development [Duffy et al., 2004; Box et al., 2001].

The prognosis for melanoma, in turn, depends on the patient's clinical parameters, as well as the histological parameters of the tumour. The histological parameters of the tumor at detection are of crucial importance, especially Breslow's thickness and ulceration. Surgery being the only effective treatment for melanoma, early detection of the disease ensures better life expectancy for the patient.

\footnotetext{
* In clinical practice general usage designates that a "mutation" causes disease, whereas changes in genetic information that have not caused disease is referred to as a "polymorphism" [Cotton, 2002].
} 


\title{
1. THE AIM, TASKS AND HYPOTHESIS OF THE STUDY
}

\section{Hypothesis}

Prognosis for melanoma is related to the patient's clinical parameters and the histological parameters of the tumor, whereas melanoma development risk is influenced by changes in the melanoma susceptibility genes.

\begin{abstract}
Aim
To assess the epidemiology of melanoma, as well as the clinical and histological parameters in relation to the prognosis for the disease, and to determine the genetic risk factors for melanoma in the population of Latvia.
\end{abstract}

\section{Tasks}

1. To give an overview of the epidemiological, clinical and histological data of the melanoma patients treated at the Riga East University Hospital Latvian Oncology Centre (RAKUS LOC) between 1998 and 2008.

2. To assess the impact of clinical and histological parameters on the life expectancy of melanoma patients.

3. To assess the prevalence of hereditary melanoma in Latvia.

4. To analyse mutations in the CDKN2A locus and exon 2 of $C D K 4$ gene in melanoma patients with a family history of melanoma, pancreatic and cerebral tumor.

5. To analyse $M C 1 R$ gene polymorphisms in melanoma patients and control subjects and to determine the melanoma development risk related to $M C 1 R$ gene polymorphisms. 


\section{SCIENTIFIC NOVELTY AND PRACTICAL VALUE OF THE STUDY}

\section{Scientific novelty}

In Latvia there have as yet been no significant epidemiological studies on melanoma. High-risk melanoma susceptibility genes $C D K N 2 A$ and $C D K 4$ have been mainly analysed in sporadic melanoma patients [Pjanova et al., 2007], whereas there has been no analysis altogether of comparatively lower-risk melanoma susceptibility genes. In the framework of the present study, mutation of the CDKN2A gene, i.e. deletion in the gene $C D K N 2 A / p 14^{A R F}$ promoter region, was for the first time discovered in a Latvian melanoma patient. Analysis of gene $C D K 4$ led to identifying the second and third melanoma family with mutation $\mathrm{R} 24 \mathrm{H}$. Haplotype analysis of all the three families with gene $C D K 4 \mathrm{R} 24 \mathrm{H}$ mutation indicates a potential founder mutation in the Latvian population.

\section{Practical value}

With a growing incidence of melanoma and given the potential genetic predisposition to melanoma, both patients and doctors need to be informed about genetic examination as an option for individuals with recurring melanoma cases in family history. Individuals with a family history of melanoma should be offered gene $C D K N 2 A$ and $C D K 4$ analysis to facilitate identification of those individuals who have a higher melanoma risk. With regard to their personal history, individuals with recurring melanoma in family history should be regularly inspected by a dermatologist or oncologist. Timely education of high-risk melanoma patients on methods of selfexamination and the crucial role of UV radiation in development of melanoma can ensure better life expectancy indicators for melanoma cases. Practical recommendations for education and examination of high risk melanoma persons based on the study results is planned to include in Latvian guidelines for the management of CMM. 


\section{MATERIAL AND METHODS}

\subsection{Study design}

The study consisted of two parts: 1) assessment of melanoma epidemiology, analysis of clinical and histological parameters of melanoma in Latvia, based on the Riga East University Hospital Latvian Oncology Centre (RAKUS LOC) archive data and 2) genetic analysis of melanoma patients conducted in collaboration with the Latvian Biomedical Research and Study Centre.

\subsection{Analysis of epidemiological, clinical and histology data of melanoma patients}

984 CMM patients treated at the RAKUS LOC in the period between the January 1st, 1998 and the December 31st, 2008 were recorded.

Inclusion criteria: all patients with confirmed histology of primary CMM were included in the study. If a patient had had more than one primary melanoma only the first melanoma was analysed.

Exclusion criteria: CMM relapse patients and patients with skin metastases with an unknown primary tumour localisation were excluded.

For each patient information about age, gender, tumour localisation, histology subtype, Breslow thickness of the melanoma, Clark invasion level, ulceration, presence of pigmentation, predominant cell type and clinical stage was recorded. Each patient was followed-up until October 2011 and the overall survival was determined.

The changes in CMM incidence (the number of new cases per 100000 inhabitants) in RAKUS LOC over the time were analysed by the autoregressive model. Both the overall time trend and trends within subcategories of patients and melanoma characteristics were studied. The models were fitted by the least squares regression in $\mathrm{R}$ [Spector, 2008].

The association between patient gender and age and the above mentioned melanoma characteristics was assessed by a Pearson's Chi-square test. When there was a natural ordering for categories of a melanoma characteristic, Cochran-Armitage trend test was used to assess the strength of the association between this characteristic and patient's gender or age group. This test was used for the clinical stage and for the Clark level of invasion. Difference between medians of Breslow thickness and age for two groups of patients was assessed by the non-parametric Mann-Whitney test. 
All patient and melanoma characteristics were studied for their impact upon the survival rates. The overall survival was analysed by the Kaplan-Meier estimator. The significance of the difference between the survival of various classes of patients was assessed by the logrank test and a Bonferroni correction was applied to the obtained pvalues. Hazard ratio (HR) and $95 \%$ confidence interval $(95 \% \mathrm{CI})$ were computed for each parameter.

\subsection{Genetic analysis of melanoma patients}

In genetic study patients were involved in collaboration with RAKUS LOC.

Inclusion criteria: voluntary basis, confirmed histology of CMM, completed questionnaire.

Exclusion criteria: incomplete questionnaire.

Genetic analysis involved 228 melanoma patients whose anamnesis, clinical and histological data were summarised and analysed. Additionally, the patients involved filled out a questionnaire designed especially for the study on pigmentation phenotype and sun-related behaviour. The patients with a family history of melanoma were repeatedly examined by a dermatologist and patient phenotyping was carried out. Data on skin colour, eye and hair colour, amount of freckles, amount and size of nevi were recorded. Further patient grouping for genetic analysis depended on their predisposition level to melanoma, i.e. in potentially predisposed patients the high-risk melanoma susceptibility genes $C D K N 2 A$ and $C D K 4$, as well as the $M C I R$ gene were analysed. In all other patients only the MCIR gene was analysed.

For analysis of MC1R gene polymorphisms 200 patients with diagnosis of melanoma and available information on pigmentation phenotype were selected. In order to assess the role of $M C 1 R$ gene polymorphisms in the development of melanoma, analysis included also 200 well-described control subjects of the age of 18 to 79 years. Similarly to the patients, the control subjects filled out a specially designed questionnaire about their pigmentation phenotype and sun-related behaviour.

Blood samples were collected from all the subjects involved in the research and transferred to the Genome Centre of Latvia where genomic DNA was isolated according to a single protocol. 


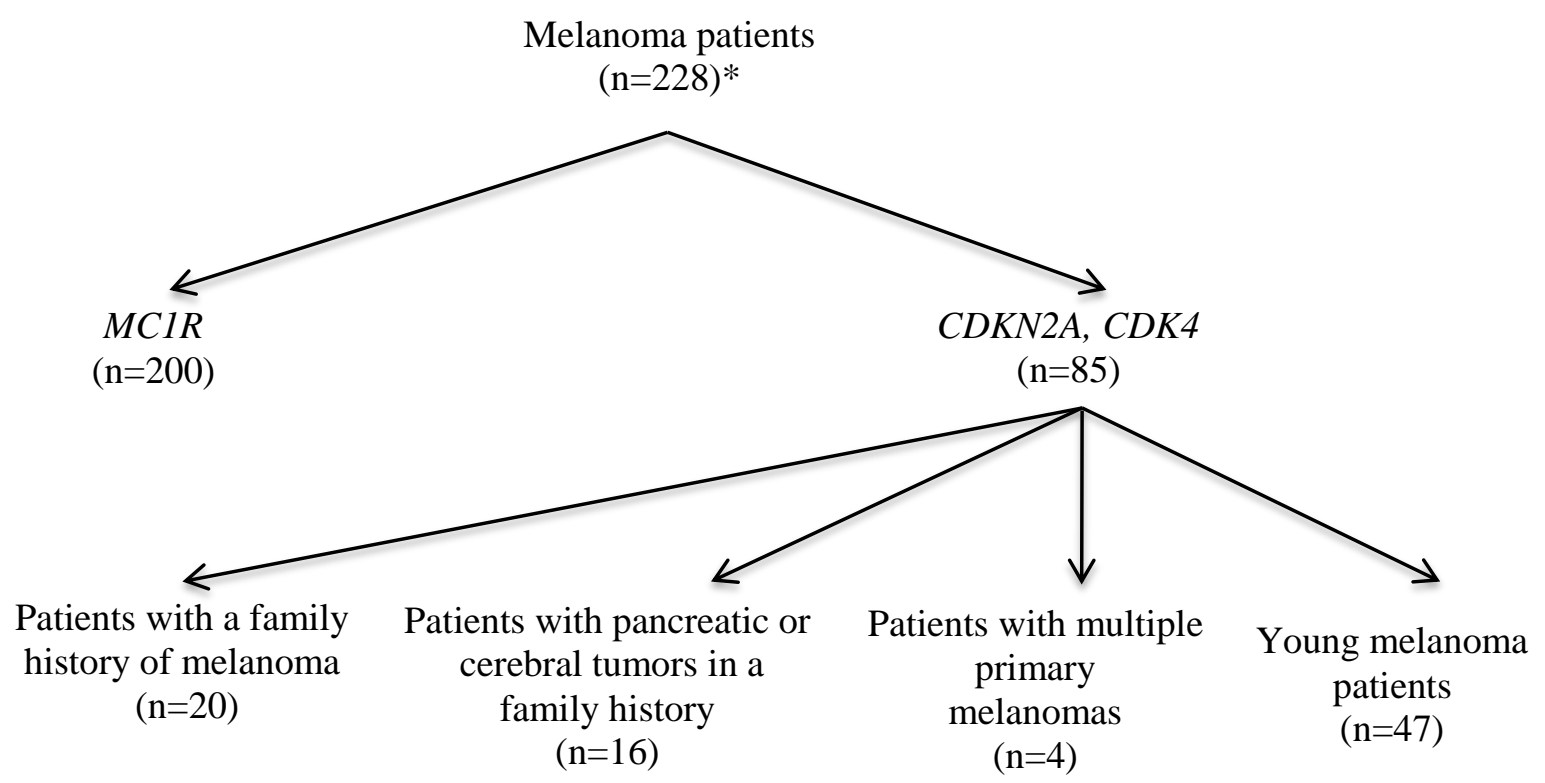

Figure 3.1 Schematic diagram of the performed genetic analysis

* some of the patients were included in both - CDKN2A,CDK4 and MCIR gene analysis

\subsubsection{Analysis of high-risk melanoma susceptibility genes $C D K N 2 A$ and $C D K 4$}

$C D K N 2 A$ and $C D K 4$ gene analysis was conducted for four groups of melanoma patients (Fig. 3.1). For the abovementioned patients gene $C D K N 2 A$ exons $1 \alpha, 1 \beta, 2$ and 3, and gene CDK4 exon 2 were analysed. Standard PCR and reagents from MBI Fermentas (Lithuania) were used for exon amplification as per manufacturers' instruction. For primer sequences refer to the full thesis. Sequencing reactions were carried out using ABI PRISM ${ }^{\circledR}$ BigDye ${ }^{\mathrm{TM}}$ Terminator Cycle Sequencing kit (Applied Biosystems, US).

In familial melanoma patients and patients with a family history of pancreatic or central nervous system tumors, gene $C D K N 2 A / p 16$ promoter region and introns 1 and 2 were additionally analysed. Fragments were amplified using standard PCR and reagents from MBI Fermentas (Lithuania). For primer sequences refer to the full thesis. In familial melanoma patients and patients with a family history of pancreatic or central nervous system tumors with no detected mutations in gene CDKN2A and exon 2 of gene $C D K 4$, deletions in $C D K N 2 A$ locus were also analysed. Deletions in $C D K N 2 A$ locus were analysed with the multiplex ligation-dependent probe amplification (MLPA) 
method by the use of the SALSA MLPA kit ME024-A1 (MRC-Holland, the Netherlands), containing 20 probes against 9p21/CDKN2A locus, 10 probes against other $9 p$ chromosome genes and 12 control probes outside $9 p 21$ locus.

In order to compare the families with each other and also to compare them with other families with detected $C D K 4 \mathrm{R} 24 \mathrm{H}$ mutation, the families with $\mathrm{R} 24 \mathrm{H}$ mutation in gene $C D K 4$ were haplotyped. Haplotyping was done as described by Molven et al., 2005 .

\subsubsection{Analysis of low-risk melanoma susceptibility gene $M C 1 R$}

Amplification of $M C 1 R$ gene coding sequence was carried out with the following primers: MC1R F 5' GCA GCA CCA TGA ACT AAG CA 3' and MC1R R 5' CAG GGT CAC ACA GGA ACC A 3' (prof. J. Newton-Bishop, personal communication) and reagents from MBI Fermentas (Lithuania). The sequencing again was carried out using ABI PRISM ${ }^{\circledR}$ BigDye ${ }^{\mathrm{TM}}$ Terminator Cycle Sequencing kit (Applied Biosystems, US). To assess the potential impact of the detected gene $M C 1 R$ polymorphisms on the receptor functions, their functionality was analysed in silico with the open access tool PolyPhen-2 [Adzhubei et al., 2010].

To determine the melanoma development risk related to $M C 1 R$ gene polymorphisms in Latvia, melanoma patients and control subjects were compared. Odds ratio $(O R), 95 \%$ confidence interval $(95 \% C I)$ and p-values were calculated with the $\chi^{2}$ method. Analysis was carried out with the internet open access calculator SISA (Simple Interactive Statistical Analysis). Age differences between the patient and control subject groups were determined with Student's t-test (GraphPad Software QuickCalcs). Compliance of genotypes with Hardy-Weinberg equilibrium and haplotypes were determined with the PLINK 1.07 software [Purcel et al., 2007].

Initially statistical analysis included each $M C 1 R$ gene polymorphism separately. Subsequently, cases of $M C 1 R$ gene polymorphisms were grouped according to two criteria and analysed by group. One criterion for grouping was by number of polymorphisms per individual, i.e.:

- "at least one", i.e. the individual has at least one non-synonymous polymorphism;

- $\quad$ "one", i.e. the individual has only one non-synonymous polymorphism; 
- "two and more", i.e. the individual has at least two non-synonymous polymorphisms.

The other criterion for grouping was according to the type of polymorphism, i.e. in polymorphisms proved to be related to the red hair phenotype (RHC) and polymorphisms without such a relationship (NRHC), i.e.:

- RHC - Asp84Glu, Arg151Cys, Arg160Try;

- NRHC - other non-synonymous polymorphisms.

In all cases the wild type (WT) group included also those individuals who had only synonymous polymorphisms. 


\section{RESULTS}

\subsection{The epidemiology of melanoma}

The mean annual incidence of melanomas was 5.5 per 100,000 inhabitants in the studied cohort. An ascending trend in the number of diagnoses was observed over time (there were 1.99 more cases per 100,000 inhabitants in 2008 than in 1998) (coefficent $\left.=0.56 ; 95 \% \mathrm{CI}=0.15-1.05 ; \mathrm{p}=9.67 \times 10^{-3}\right)($ Fig. 4.1).

There were $640(65 \%)$ females and $344(35 \%)$ males among the total of 984 patients included in the study, with male to female ratio of 0.54 . The mean age of a patient was $61.3( \pm 15.3)$ years with a median age of 63.4 years. Female patients were slightly older than males (Table 4.1). Median age changes observed during the study were not statistically significant.

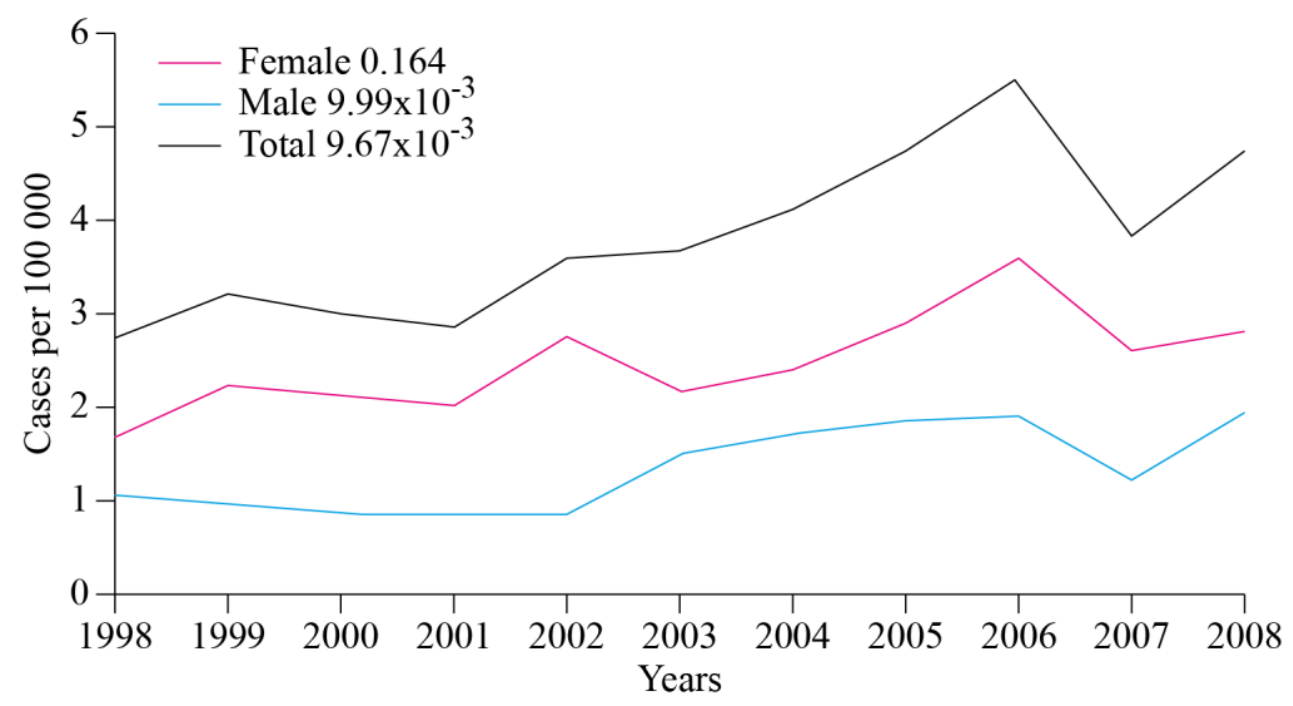

Figure 4.1 Melanoma incidence trends in RAKUS LOC during the time period from year 1998 to 2008

979 or $95.5 \%$ of all patients were diagnosed with a single primary melanoma and only five patients $(0.5 \%)$ had developed several primary melanomas during the observation time. The most frequent melanoma localisation was the trunk $(38.2 \%$ of cases or 376 patients) followed by the extremities (48.6\% or 478 patients). There was an enrichment of females among the patients with melanoma localisation on extremities in comparison with other localisations (59.5\%), whereas male patients had an excess of melanomas on the trunk $\left(59.3 \%, \mathrm{p}=5.0 \times 10^{-4}\right)$ and on the head and the neck $(11.3 \%$; $\left.\mathrm{p}=9.96 \times 10^{-3}\right)($ Table 4.1$)$. During the study period a significant increase in the number 
of melanomas localised on the trunk was pointed out (AR coefficent $=0.752 ; 95 \% \mathrm{CI}$ $\left.0.411-1.092 ; 1.55 \times 10^{-5}\right)$.

More than half of all analysed cases (536 or 54.5\%) had an unidentified tumour subtype. Most of the remaining cases (386 or 39.2\%) were described as nodular, while $40(4.1 \%)$ were superficial spreading melanomas (SSM), and $15(1.5 \%)$ of cases were confirmed as lentigo maligna. Only seven patients $(0.7 \%)$ were diagnosed with in situ melanoma. No significant alterations of the incidence were observed for various melanoma subtypes.

Table 4.1

Age and melanoma characteristics of analysed patients

\begin{tabular}{|c|c|c|c|}
\hline Parameter & Total, n (\%) & Females, n (\%) & Males, n (\%) \\
\hline \multicolumn{4}{|l|}{ Age } \\
\hline Mean (SD) & $61.3( \pm 15.3)$ & $61.6( \pm 15.6)$ & $60.7( \pm 14.7)$ \\
\hline Median & 63.4 & 64.2 & 62.6 \\
\hline \multicolumn{4}{|c|}{ Localisation of CMM } \\
\hline Head and neck & $123(12.5)$ & $84(13.1)$ & $39(11.3)$ \\
\hline Trunk & $376(38.2)$ & $172(26.9)$ & $204(59.3)$ \\
\hline Arm & $158(16.1)$ & $116(18,1)$ & $42(12.2)$ \\
\hline Leg & $320(32.5)$ & $265(41.4)$ & $55(16.0)$ \\
\hline Genital region & $7(0.7)$ & $3(0.5)$ & $4(1.2)$ \\
\hline Total & $984(100.0)$ & $640(100.0)$ & $344(100.0)$ \\
\hline \multicolumn{4}{|c|}{ Breslow thickness (mm) } \\
\hline Mean (SD) & $6.0( \pm 6.8)$ & $5.9( \pm 7.0)$ & $6.2( \pm 6.5)$ \\
\hline Median & 4.0 & 4.0 & 4.0 \\
\hline \multicolumn{4}{|l|}{ Ulceration } \\
\hline Present & $445(45.2)$ & $283(44.2)$ & $162(47.1)$ \\
\hline Absent & $275(28.0)$ & $186(29.1)$ & $89(25.9)$ \\
\hline $\mathrm{Nd}$ & $264(26.8)$ & $171(26.7)$ & $93(27.0)$ \\
\hline \multicolumn{4}{|l|}{ Pigment } \\
\hline Present & $797(80.9)$ & $525(82.0)$ & $272(79.1)$ \\
\hline Absent & $94(9.6)$ & $60(9.4)$ & $34(9.9)$ \\
\hline nd & $93(9.5)$ & $55(8.6)$ & $38(11.0)$ \\
\hline \multicolumn{4}{|c|}{ Melanoma subtype } \\
\hline In situ & $7(0.7)$ & $5(0.8)$ & $2(0.6)$ \\
\hline SSM & $40(4.1)$ & $23(3.6)$ & $17(4.9)$ \\
\hline Nodular & $386(39.2)$ & $246(38.4)$ & $140(40.7)$ \\
\hline Lentigo maligna & $15(1.5)$ & $12(1.9)$ & $3(0.9)$ \\
\hline nd & $536(54.5)$ & $354(55.3)$ & $182(52.9)$ \\
\hline
\end{tabular}

SD - standart deviation, nd - no data, SSM - superficial spreading melanoma

Ulceration was present in 445 or $45.2 \%$ of cases and absent in $275(28.0 \%)$ cases (in 264 cases information about ulceration was not documented). Ulcerated melanomas were more widespread among males (47.1\%) than females $(44.2 \%)$ 
$(\mathrm{p}=0,078)$ however these differencies were not statistically significant. Most of all melanomas ( 797 or $80.9 \%$ ) were pigmented and only 94 or $9.6 \%$ were amelanotic (Table 4.1). A significant increase in non-ulcerated melanomas (AR coefficent $=0.85$; $95 \% \mathrm{CI}=0.43-1.28 ; \mathrm{p}=8.13 \times 10^{-5}$ ) and a decrease in amelanotic melanomas, however, non-significant was detected (Table 4.1).

The mean melanoma Breslow thickness was $6.0 \mathrm{~mm}( \pm 6.8 \mathrm{~mm})$ with a median thinkness of $4.0 \mathrm{~mm}$ ranging from $0.02 \mathrm{~mm}$ to $65.00 \mathrm{~mm}$. The mean Breslow thickness was slightly higher for males $(6.2 \mathrm{~mm} \pm 6.5 \mathrm{~mm})$ than for females $(5.7 \mathrm{~m} . \pm 7.0 \mathrm{~mm})$ $(\mathrm{p}=0,0137)$. During the study period, there was observed the decrement of tumour Breslow thickness. However, this decrement was significant only for mean (coefficent= $-0.37 ; 95 \% \mathrm{CI}=-0.60$ to $-0.15 ; \mathrm{p}=0.005)$ and not significant for median tumour thickness (coefficent $=-0.11 ; 95 \% \mathrm{CI}=-0.28$ to $0.06 ; \mathrm{p}=0.186)($ Table 4.2$)$.

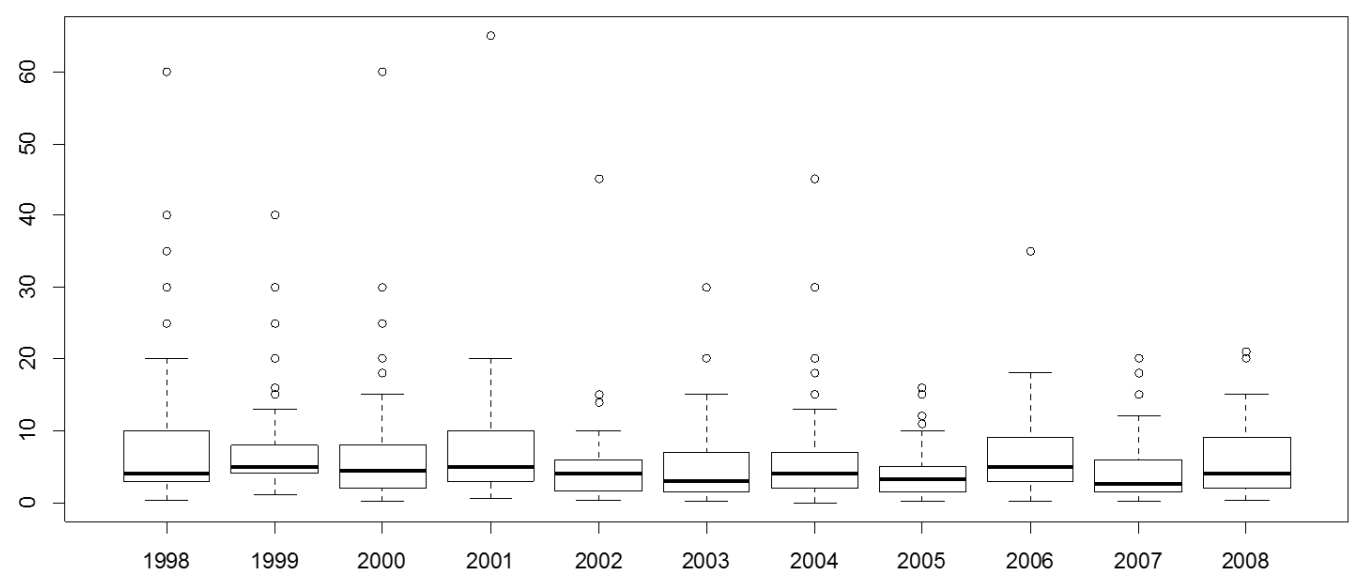

Figure 4.2 Variations in melanoma Breslow thickness from 1998 to 2008: box plots showing variation of tumour thickness $(\mathbf{m m})$ by year

Analysis of cell types of CMM revealed that an epitheloid cell melanoma comprised 520 or $52.9 \%$ of cases followed by a spindle cell and mixed cell melanoma ( $14.6 \%$ or 144 cases and $12.7 \%$ or 125 cases respectively). The analysis of the clinical stage distribution showed that the majority of tumors were stage II C melanomas (198 patients $(20,1 \%))$.

The association of the age with different melanoma characteristics was analysed next (Table 4.2). For this purpose the patients were divided into two age groups $(\leq 63$ 
and $>63$ years) and the age distribution across these groups was assessed for each clinical or histopathological feature.

Table 4.2

Distribution of melanoma patients by age in relation to tumour localisation and histopathological features

\begin{tabular}{|c|c|c|c|}
\hline Parameter & Pacienti, n (\%) & $\leq 63$ years, $n(\%)$ & $>63$ years, $n(\%)$ \\
\hline \multicolumn{4}{|l|}{ Gender } \\
\hline Females & $640(65.0)$ & $318(62.8)$ & $322(67.4)$ \\
\hline Males & $344(35.0)$ & $181(37.2)$ & $156(32.6)$ \\
\hline Total & $984(100.0)$ & $506(100.0)$ & $478(100.0)$ \\
\hline \multicolumn{4}{|l|}{ Tumor site } \\
\hline Head and neck & $123(12.5)$ & $37(7.5)$ & $86(17.6)$ \\
\hline Trunk & $376(38.2)$ & $220(43,1)$ & $156(33.2)$ \\
\hline Arm & $158(16.1)$ & $78(15.5)$ & $80(16.6)$ \\
\hline Leg & $320(32.5)$ & $166(32.9)$ & $154(32.2)$ \\
\hline G̦enital region & $7(0.7)$ & $5(1.0)$ & $2(0.4)$ \\
\hline \multicolumn{4}{|c|}{ Breslow thickness, mm } \\
\hline Mean (SD) & $6.0(6.8)$ & $5.4(6.2)$ & $6.6(7.3)$ \\
\hline Median & 4.0 & 3.8 & 5.0 \\
\hline \multicolumn{4}{|l|}{ Ulceration } \\
\hline Present & $445(45.2)$ & $197(38.9)$ & $248(51.9)$ \\
\hline Absent & $275(28.0)$ & $165(32.6)$ & $110(23.0)$ \\
\hline nd & $264(26.8)$ & $144(28.5)$ & $120(25.1)$ \\
\hline \multicolumn{4}{|l|}{ Pigment } \\
\hline Present & $797(80.9)$ & $418(82.6)$ & $379(79.3)$ \\
\hline Absent & $94(9.6)$ & $36(7.1)$ & $58(12.1)$ \\
\hline nd & $93(9.5)$ & $52(10.3)$ & $41(8.6)$ \\
\hline \multicolumn{4}{|l|}{ Melanoma subtype } \\
\hline In situ & $7(0.7)$ & $3(0.6)$ & $4(0.8)$ \\
\hline SMM & $40(4.1)$ & $26(5.1)$ & $14(2.9)$ \\
\hline Nodular & $386(39.2)$ & $185(36.6)$ & $201(42.1)$ \\
\hline $\begin{array}{l}\text { Lentigo maligna } \\
\text { melanoma }\end{array}$ & $15(1.5)$ & $9(1.8)$ & $6(1.3)$ \\
\hline nd & $536(54.5)$ & $283(55.9)$ & $253(52.9)$ \\
\hline
\end{tabular}

SD - standart deviation, nd - no data, SSM - superficial spreading melanoma

The predominance of the head and neck melanomas among the elderly patients $\left(>63\right.$ years) was revealed $\left(\mathrm{p}=5.02 \times 10^{-5}\right)$. Amelanotic and ulcerated melanomas were more widespread among the elderly ( $\mathrm{p}=0.013$ and $4.7 \times 10^{-5}$ respectively) and their melanomas tended to be thicker according to melanoma Breslow thickness $\left(\mathrm{p}=9.79 \times 10^{-}\right.$ ${ }^{5}$ ) (Table 4.2).

The Kaplan-Meier curves showed a better overall prognosis for females than for males $\left(\mathrm{HR}=1.48 ; 95 \% \mathrm{CI}=1.22-1.81\right.$, p-value $\left.7.40 \times 10^{-5}\right)$ (Fig. $4.3(\mathrm{~A})$ ). The primary 
tumour localisation did not play a significant role for survival, except in males with melanoma on extremities $\left(\mathrm{HR}=2.29 ; 95 \% \mathrm{CI}=1.67-3.14, \mathrm{p}=1.14 \times 10^{-7}\right)($ Fig. $4.3(\mathrm{~B}))$.

A

gender

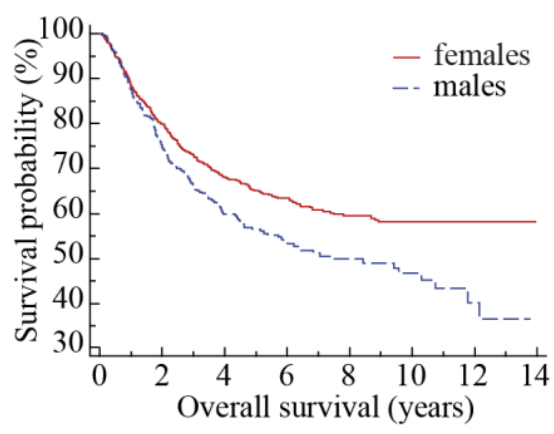

B localisation

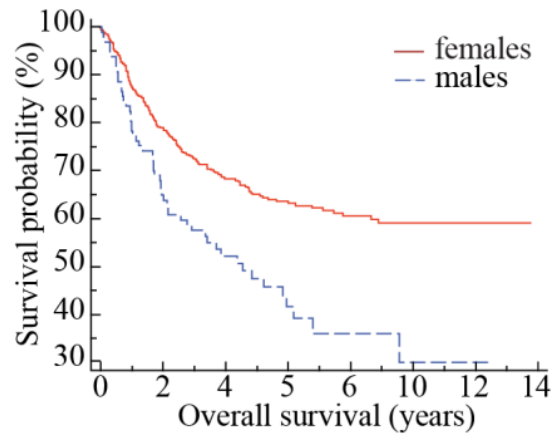

Figure 4.3 Kaplan-Meier curves for differences in overall survival: (A) by gender, (B) by gender and melanoma localisation

As expected, patients with a superficial spreading melanoma had better prospects than patients with a nodular melanoma $(\mathrm{HR}=4.13 ; 95 \% \mathrm{CI}=1.83-9.30$; $\left.\mathrm{p}=2.10 \times 10^{-4}\right)($ Fig. $4.4(\mathrm{~A})$ ), but males with nodular melanomas had worse prognosis than females with the same tumor subtype $(\mathrm{HR}=1,4 ; 95 \% \mathrm{CI}=1,0-1,9 ; \mathrm{p}=0,02)$ ( Fig. 4.4 (B)). Similarly the correlation between the Breslow thickness of the tumor and the survival rate was significant $\left(\mathrm{HR}=1.04 ; 95 \% \mathrm{CI}=1.03-1.05 ; \mathrm{p}<2 \times 10^{-16}\right)$ (Fig. $4.4(\mathrm{C})$ ). Pigmented tumors, regardless of the gender, showed brighter prospects than amelanotic melanomas $\left(\mathrm{HR}=1.91 ; 95 \% \mathrm{CI}=1.43-2.55 ; \mathrm{p}=7.16 \times 10^{-6}\right)$ (Fig. 4.4 (D)). The association between the ulceration and survival was also revealed: survival was better for patients without an ulceration $\left(\mathrm{HR}=0.40 ; 95 \% \mathrm{CI}=0.30-0.51 ; \mathrm{p}=7.23 \times 10^{-13}\right)($ Fig. $4.4(\mathrm{E}))$.

A

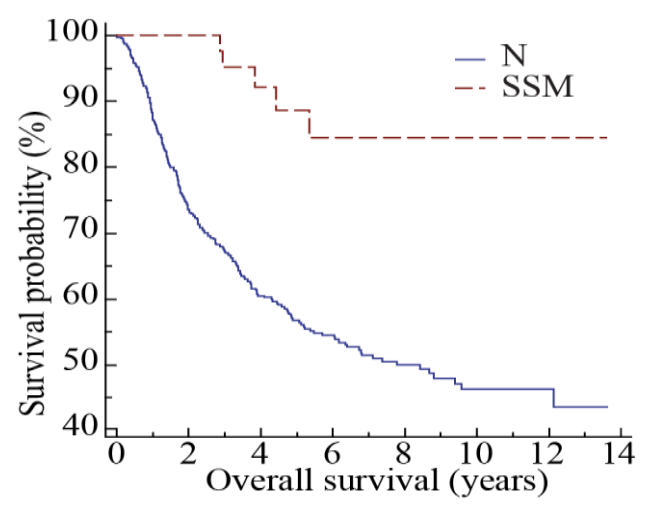

B nodular melanoma

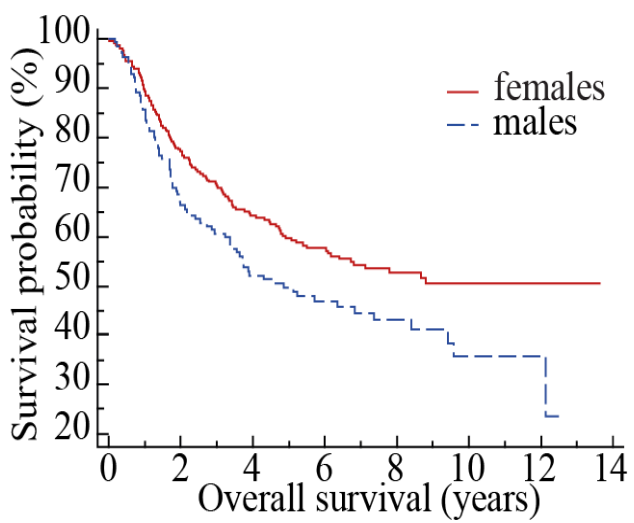


C

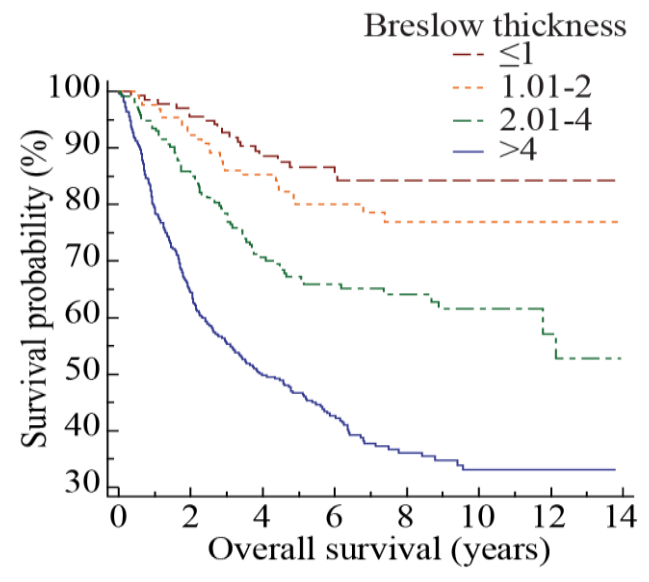

E

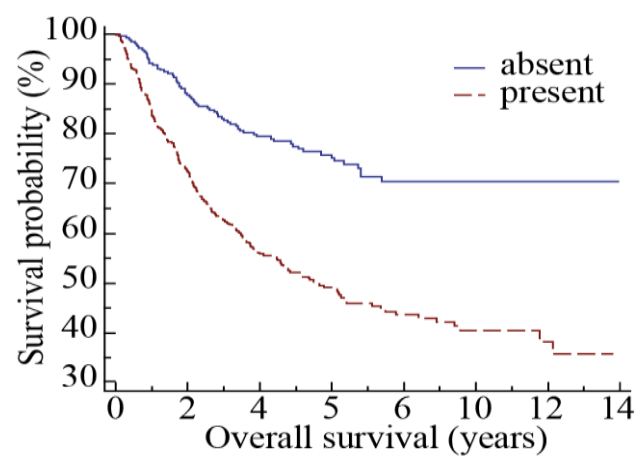

D

pigment

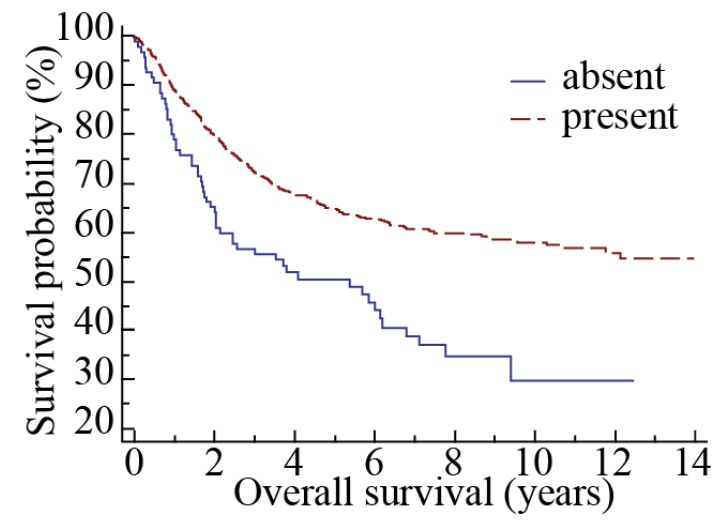

$\mathrm{F}$

ulceration

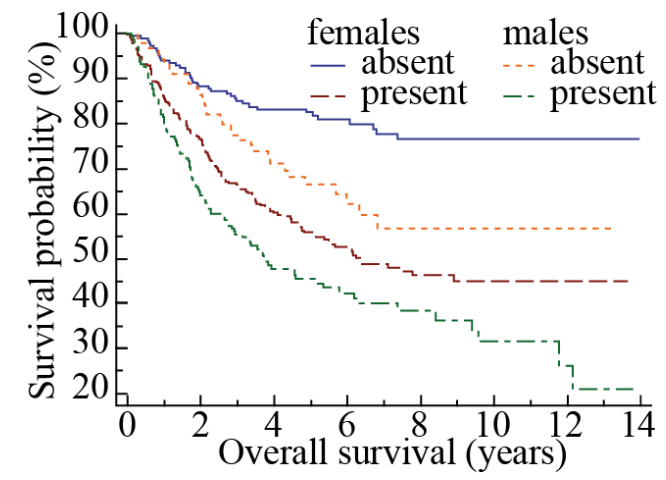

Figure 4.4 Kaplan-Meier curves for differences in overall survival: (A) by melanoma subtype, (B) by gender in case of nodular melanoma, (C) by tumor Breslow thickness, (D) by presence of pigment, (E) by presence of ulceration, (d) by presence of ulceration and gender

Moreover, the prognosis for females with ulcerated tumors seemed to be better than for males with the same tumour characteristic, although this trend did not reach a statistical significance after Bonferroni correction was applied (Fig. 4.4 (F)). There was no correlation between the cell type of melanoma and a patient's survival $(\mathrm{HR}=0.99$; 95\% CI $=0.86-1.13 ; p=0.828$ ) (Fig. 2f). In contrast, the association between the clinical stage and the survival was clearly evident $\left(\mathrm{HR}=1.72 ; 95 \% \mathrm{CI}=1.54-1.91 ; \mathrm{p}<2 \times 10^{-16}\right)$. 


\subsection{Genetic changes in melanoma patients}

\subsubsection{Characteristics of patients enrolled in the genetic analysis}

143 patients $(62,7 \%)$ of those enrolled in the genetic study were with sporadic melanomas. 20 patients $(8,8 \%)$ had family history of melanoma (Table 4.3$)$.

Table 4.3

Melanoma patients enrolled in the genetic study

\begin{tabular}{|c|c|c|}
\hline Characteristics of melanoma patients & $\begin{array}{c}\text { Patients } \\
(\text { n) }\end{array}$ & $\begin{array}{c}\text { Patients } \\
(\%)\end{array}$ \\
\hline Melanoma patients with family history of melanoma: & 20 & 8,8 \\
\hline 3 and more melanoma cases in the family* & 3 & 1,3 \\
\hline $\begin{array}{l}2 \text { melanoma cases in the family, melanoma in a first- } \\
\text { degree relative }\end{array}$ & 12 & 5,3 \\
\hline $\begin{array}{l}2 \text { melanoma cases in the family, melanoma in a distant } \\
\text { relative }\end{array}$ & 5 & 2,2 \\
\hline $\begin{array}{l}\text { Melanoma patients with a family history of pancreatic } \\
\text { cancer }\end{array}$ & 7 & 3,7 \\
\hline Melanoma patients with a family history of CNS cancer & 9 & 3,9 \\
\hline Melanoma patients with multiple primary melanomas & 3 & 1,3 \\
\hline Young melanoma patients ( $\leq 40$ gadi) & 46 & 20,2 \\
\hline Patients with sporadic melanoma & 143 & 62,7 \\
\hline Total & 228 & 100 \\
\hline
\end{tabular}

* one of the melanoma families included in the study was described previously, in the present study it was analised in more detail

\subsubsection{Mutations in high-risk melanoma susceptibility genes $C D K N 2 A$ and CDK4 in patients with family history of cancer}

Mutations in the high-risk melanoma susceptibility genes $C D K N 2 A$ and $C D K 4$ were analysed in all the 20 patients with familial melanoma irrespectively of the degree of kinship. This group included also 7 patients with a family history of pancreatic tumor and 9 patients with a family history of CNS tumors ( 8 brain tumors and 1 tumor of the spinal cord). The total number of patients analysed in this group was 36 . For all the 36 patients of the group, the mutations in the encoding parts of gene $C D K N 2 A(1 \alpha, 1 \beta$, exons 2 and 3) were analysed, including splice sites and 3' untranslated region. Mutations in exon 2 of gene $C D K 4$ were also analysed in all the patients of this group.

None of the 36 patients analysed was found to have any gene $C D K N 2 A$ mutations during analysis of the encoding part of the gene and its adjacent regions. Three polymorphisms previously described in literature, i.e. c.442G>A (Ala148Thr) 
(rs3731249) in exon 2, c. ${ }^{*} 29 \mathrm{G}>\mathrm{C}$ (rs11515) and c. ${ }^{* 69 C}>\mathrm{T}$ (rs3088440) in 3' untranslated region, were detected [Kumar et al., 2001; Debniak et al., 2005; Pjanova et al., 2007]. For all the 36 patients of the group exon 2 of gene $C D K 4$ was sequenced. Gene $C D K 4$ mutation c.71G>A $(\mathrm{R} 24 \mathrm{H})$ was detected in three patients. All the three patients with gene $C D K 4$ mutation had a strong family history of melanoma. Each of the three respective family histories demonstrated five melanoma cases.

The first patient (M268) with a detected gene CDK4 mutation $\mathrm{R} 24 \mathrm{H}$ was a woman with two diagnosed primary melanomas: one on the upper arm at the age of 33, and the other one on the lower leg at the age of 75 . No histological description of the first melanoma was available. The second melanoma histologically is a superficially spreading melanoma without ulceration, of Clark level IV, $1 \mathrm{~mm}$ Breslow thickness. The histological description contains no information about type of melanoma, cell type or presence of pigmentation. The patient had skin type II, brown hair, brown eyes and multiple nevi. In the period between the two incidences of melanoma, the patient had been operated for two basal-cell carcinomas removed from the skin of her face. The patient's family history revealed four other melanoma cases (Fig. 4.5). The mean age at which melanoma was diagnosed in the family was 39.5 years. 
I

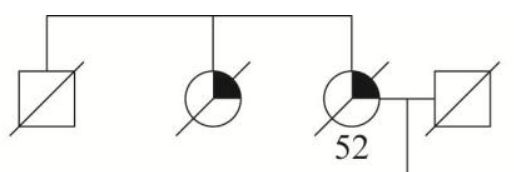

II

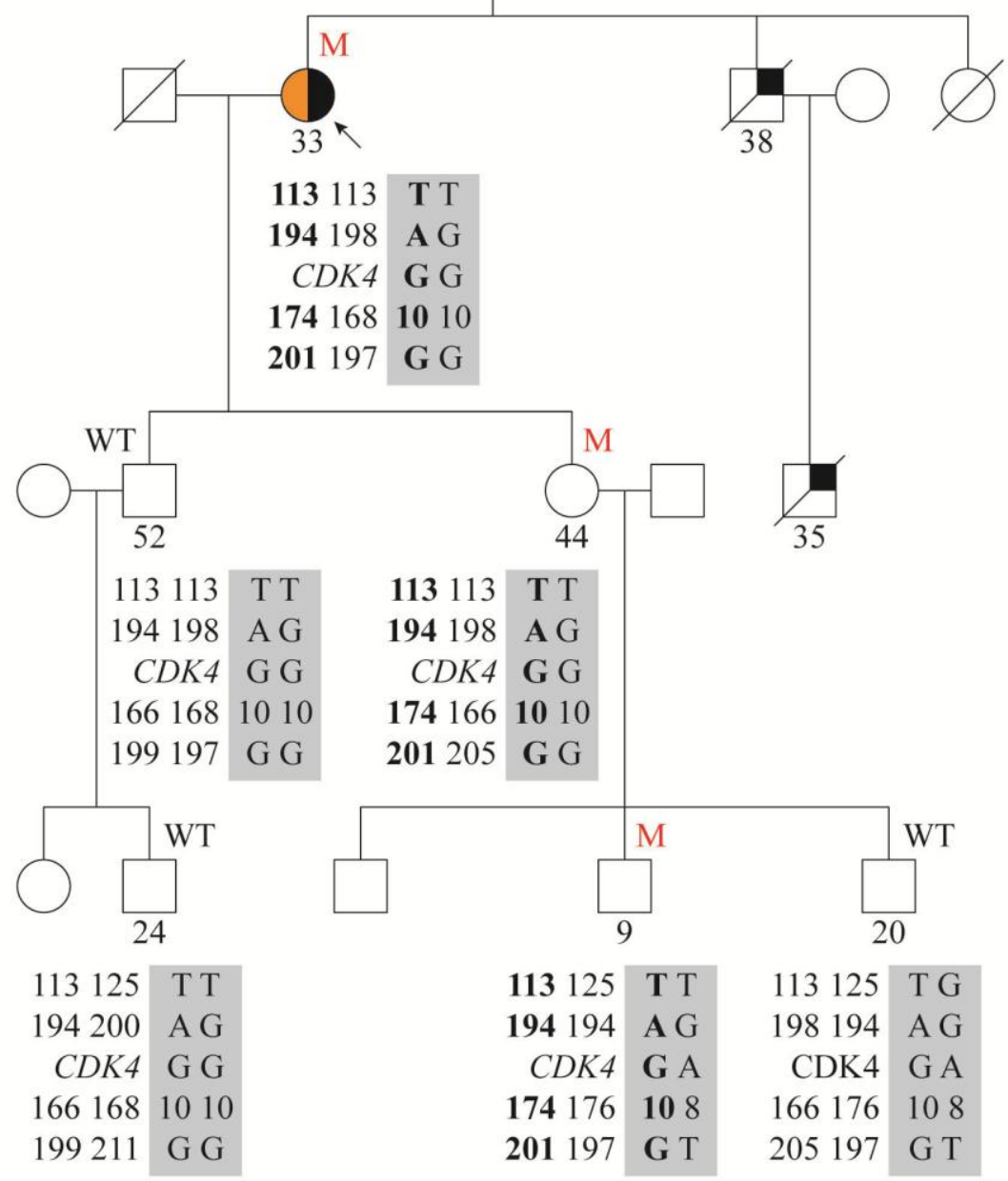

III

- proband

M - mutation R24H

WT - wild type

- melanoma

- basal cell carcinoma

33 g. - age of primary melanoma onset,

in healthy persons - age at the time of DNA test

Figure 4.5 Family tree and haplotyping results for the M268 patient with the mutation c. $71 G>A(R 24 H)$ in the gene $C D K 4$ 
Genetic analysis included also five family members who were free from disease. Two of them, i.e. the patient's daughter and grandson (daughter's son), were shown to have gene $C D K 4$ mutation $\mathrm{R} 24 \mathrm{H}$.

The second patient (M679) with an identified CDK4 mutation R24H was a man diagnosed with a primary melanoma on his back at the age of 16. A second primary melanoma on the skin of his back had been removed surgically when he was 40 . Histologically it was a superficial, epitheloid cell melanoma, pigmented, without ulceration, of Clark invasion level II and $1 \mathrm{~mm}$ Breslow thickness. The patient has skin type III, dark brown hair, blue eyes, some nevi.

The patient's family history included five melanoma cases observed over three generations (Fig. 4.6). The mean age at which melanoma was diagnosed in the family (based on the two cases where there is information about the age at which primary melanoma was diagnosed) was 29.5 years. According to the patient, his other relatives have had a number of tumor types. The family has a history of pulmonary, gastric, renal and breast cancers. Two members of the family have had pernicious anaemia.

Genetic analysis covered also family members, who were analysed for gene CDK4 mutation $\mathrm{R} 24 \mathrm{H}$. Like in the case above, they were family members free from disease: the patient's mother and daughter. The patient's daughter was found to have gene $C D K 4$ mutation $\mathrm{R} 24 \mathrm{H}$.

The third patient (M247) had been found to have gene CDK4 exon 2 mutation c.71G>A (R24H) during a prior study when between 2001 and 2004 analysis of exon 2 of gene $C D K 4$ was conducted for all melanoma patients who agreed to participate in genetic analysis [Pjanova et al., 2007]. In the framework of that study a detailed research of family history was not undertaken, this being the task of the present study. The patient was a woman who had been diagnosed with primary skin melanoma at the age of 42. Histologically it was a pigmented, epitheloid cell melanoma, of $0.5 \mathrm{~mm}$ Breslow thickness and Clark level II. The patient's family history includes four other melanoma cases (Fig. 4.7). The mean age at which melanoma was diagnosed in the family was 43.8 years.

Similarly to the previous families, genetic analysis covered also family members who were analysed for the presence of gene $C D K 4$ mutation $\mathrm{R} 24 \mathrm{H}$. 


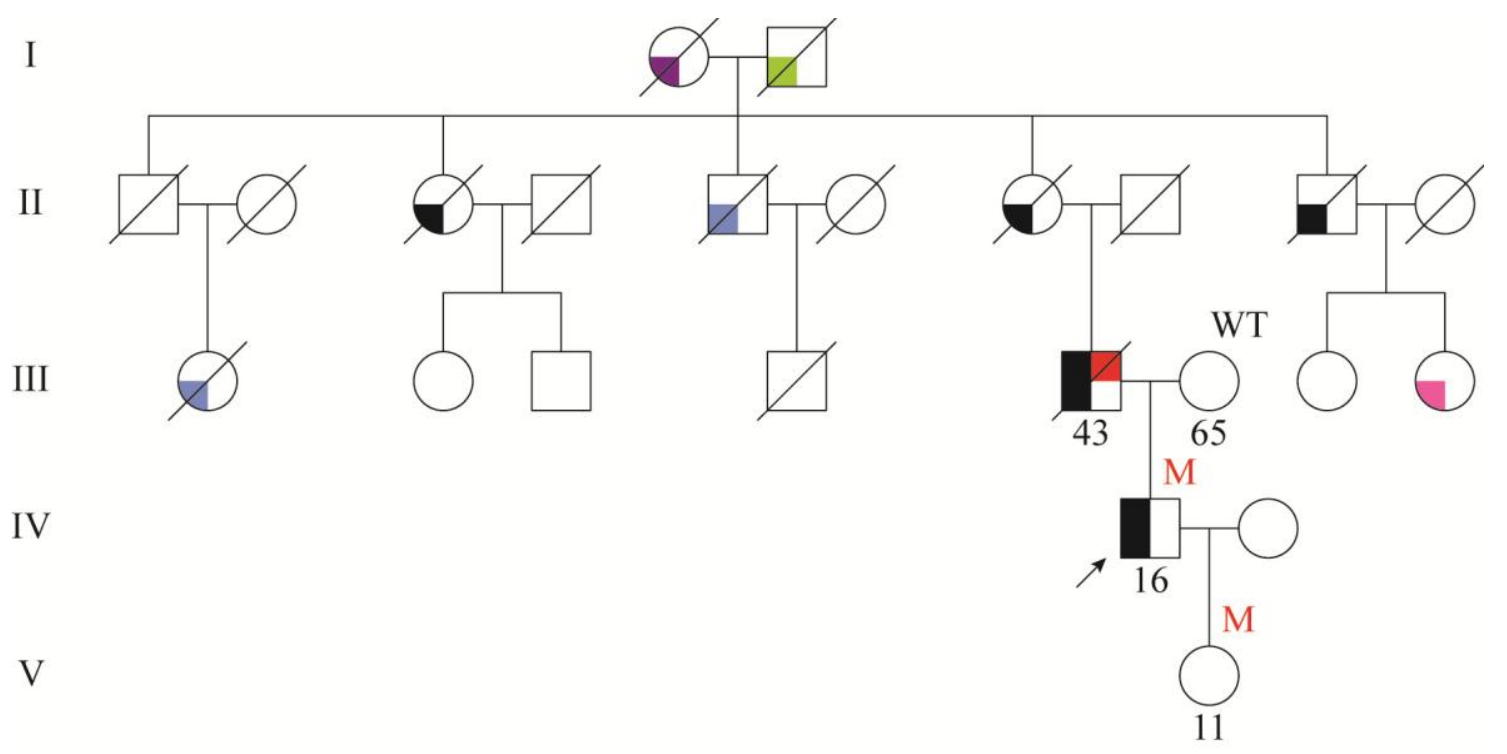

$\nearrow$ - proband

M - mutation R24H

WT - wild type

- melanoma

- pernicious anemia

- rectal cancer

- kidney cancer

- lung cancer

- gastric cancer

$43 \mathrm{~g}$. - age of primary melanoma onset,

in healthy persons - age at the time of DNA test

Figure 4.6 Family tree for the patient M679 with the mutation c.

71G>A (R24H) in the gene CDK4 


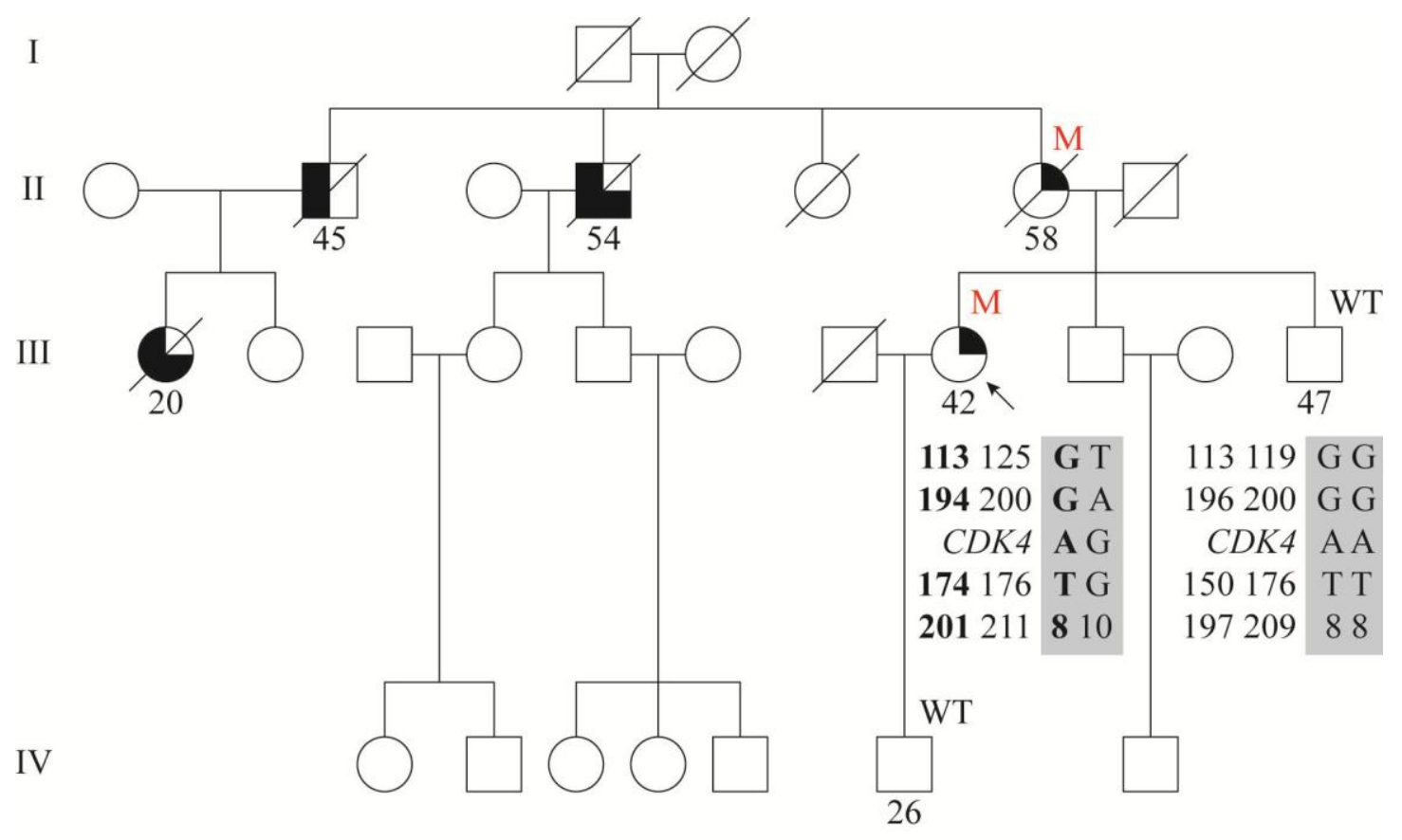

$117125 \mathrm{G} \mathrm{T}$

$198200 \mathrm{G} \mathrm{A}$

CDK4 A G

170176 T G

203211810

\footnotetext{
- proband

M - mutation R24H

WT - wild type

- melanoma
}

42 g. - age of primary melanoma onset, in healthy persons - age at the time of DNA test

\section{Figure 4.7 Family tree and haplotyping results for the M247 patient with the mutation c. $71 \mathrm{G}>\mathrm{A}(\mathrm{R} 24 \mathrm{H})$ in the gene $C D K 4$}

As before, all the relatives involved were family members who were free from the disease: the patient's son and brother. The family members who were free from the disease were not found to have gene $C D K 4$ mutation $\mathrm{R} 24 \mathrm{H}$. In this family, there was the possibility to analyse also archival paraffin embedded melanoma tissues from probands mother, where the presence of $\mathrm{R} 24 \mathrm{H}$ mutation was detected, confirming that, at least in 
this particular family, gene $C D K 4$ mutations have been inherited in relation with the disease.

A review of the phenotypic data of the gene $C D K 4$ mutation positive melanoma patients described shows that the only feature that is common for almost all the patients is the large number of nevi. According to other phenotypic criteria (skin type, hair colour and colour of eyes) the melanoma patients from the three families do not fall into the melanoma risk group (skin type I, fair/red hair, blue/green eyes). Only one out of the three patients with gene $C D K 4$ mutation had skin type I. This refers also to those $C D K 4$ mutation positive individuals who were free from the disease. They mostly had brown hair and eye colour varying from green to brown. Significant differences in phenotype were not established also when comparing the gene CDK4 mutation positive and gene CDK4 mutation negative members of one family. On the other hand, a large number of nevi were noted not only among the gene $C D K 4$ mutation positive, but also among the gene $C D K 4$ mutation negative family members.

Similarly, analysis of the histological descriptions of melanomas of patients with gene CDK4 mutations shows no regularity. Mostly they are pigmented, epithelioid-cell melanomas, which are the most commonly seen histological type also in sporadic melanoma cases.

The only feature differentiating patients with gene $C D K 4$ mutation from other melanoma patients is the age at which they have been diagnosed. Namely, at the time of diagnoses, the patients with gene CDK4 mutation were on the average younger than the patients with sporadic melanoma. The mean age at the time when primary melanoma was discovered of the patients from the gene $C D K 4$ mutation positive families analysed in the present study was 39.6 years, age median 42 . In the sporadic melanoma cases, as shown above, the mean age of the patients was 61.3 years, age median 63.3.

In order to find out the origin of the gene CDK4 mutation, region haplotyping was carried out in two of the described families (M247 and M268). For haplotype analysis we used four microsatellite markers (D12S305, CDK4M4, CDK4M1, D12S1691) adjacent to $C D K 4$ gene, three single nucleotide polymorphisms (SNPs) in gene $C D K 4$ (rs2270777, rs2069502, rs2069506), one SNP in the promoter region of the gene (rs2072052), and nucleotide repetition in gene intron 5. The results of the haplotype analysis have been shown in Fig. 4.5 and 4.7. In Latvia the haplotype related to gene $C D K 4$ mutation c.71G>A $(\mathrm{R} 24 \mathrm{H})$ is $113-194-C D K 4-174-201$ according to microsatellite markers and TAG10G according to SNPs. Comparison of the established 
haplotype with the $C D K 4$ region haplotypes in other families with gene $C D K 4$ mutation c.71G $>$ A $(\mathrm{R} 24 \mathrm{H})$ shows that the established haplotype is different, i.e. has originated independently from the other haplotypes. Moreover, the fact that the haplotype linked with mutation in both of the analysed families is the same, might point to the presence of a potential founder mutation in the Latvian population (Fig. 4.8).

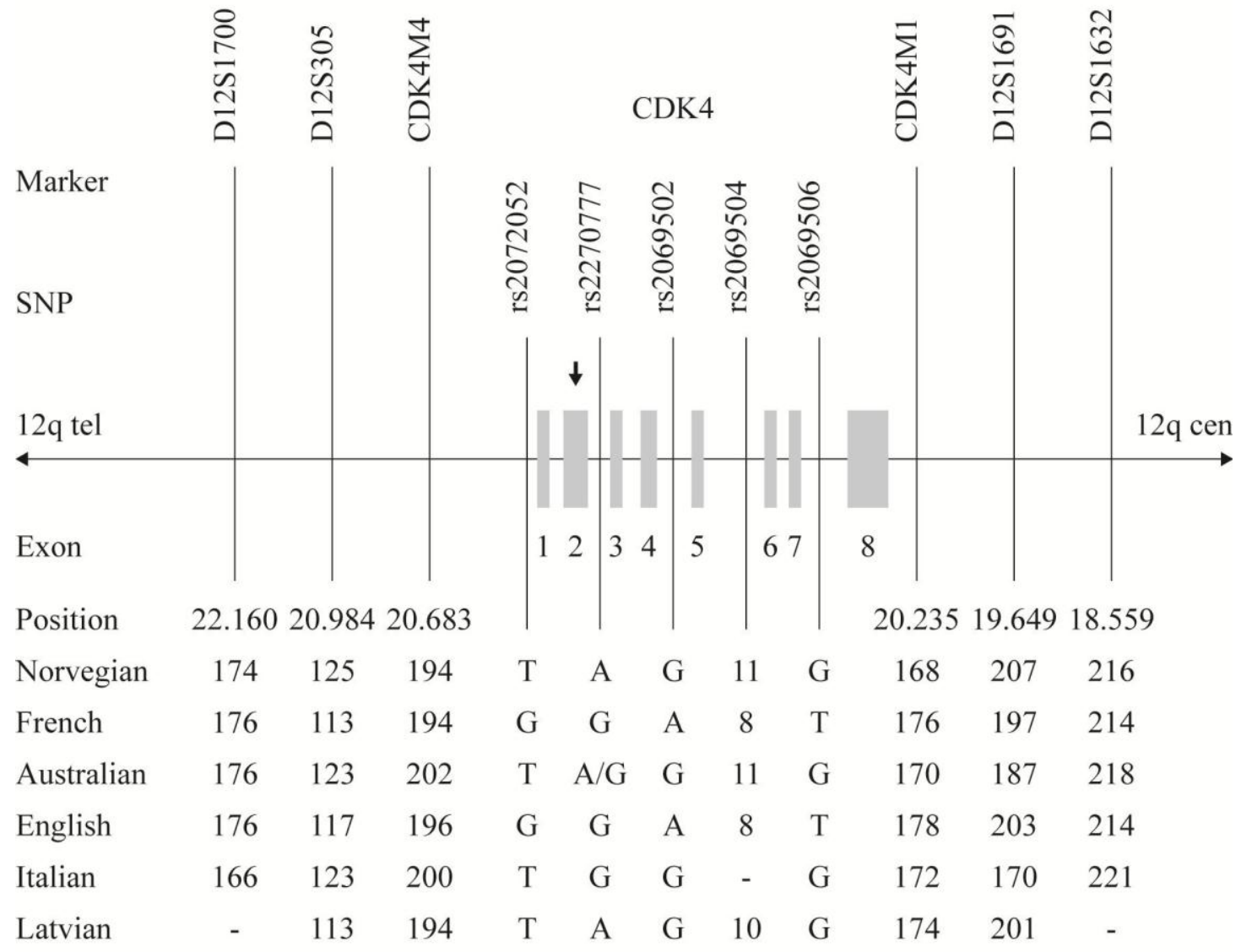

Figure 4.8 Comparison of mutation-carrying CDK4 haplotype in melanoma families

\subsubsection{Changes in gene $C D K N 2 A$ promoter and introns in patients with a family history of recurrent tumors}

In view of the fact that in melanoma families mutations are predominantly found in gene $C D K N 2 A$, whereas during our analysis of the encoding part of gene CDKN2A and its adjacent sequences no mutations were established, the gene CDKN2A/p16 promoter region and intron 1 and 2 were also sequenced. The analysis included 20 patients: 10 patients with melanoma, 4 patients with pancreatic tumor and 6 patients with brain tumor in first-degree relatives. 
The 20 patients analysed were found to have 3 different previously described polymorphisms in gene $C D K N 2 A$ promoter: c. $-191 \mathrm{~A}>\mathrm{G}$, c. $-493 \mathrm{~A}>\mathrm{T}$ and c. $-735 \mathrm{G}>\mathrm{A}$ [Harland et al., 2000; Pollock et al., 2001]. We failed to synthesize all intron fragments for three of the patients included in the analysis (because of the lack of sufficient DNA) ); therefore these three patients were excluded from further analysis. Analysis of the 17 remaining patients detected seven different polymorphisms: four of them were localized in intron 1 and three - in intron 2. Five (IVS1+459T >C, IVS1+1255C>A, IVS1$782 \mathrm{G}>\mathrm{C}, \quad$ IVS $2+227 \mathrm{~A}>\mathrm{G}, \quad$ IVS2 $+474 \mathrm{~T}>\mathrm{C}$ ) of the polymorphisms detected were previously described polymorphisms [Harland et al., 2000], but two polymorphisms $(\mathrm{IVS} 1+1569 \mathrm{~T}>\mathrm{A}$ and IVS2+82C $>\mathrm{T})$ were new sequence variations that hot been previously described.

\subsubsection{Deletions in $C D K N 2 A$ region in patients with a family history of recurrent tumors}

In view of the fact that sequencing did not reveal mutations in gene $C D K N 2 A$, analysis of deletions were carried out in the CDKN2A locus by applying the MLPA method. Analysis included the same 17 patients who had been selected for analysing gene $C D K N 2 A$ promoter and introns. One of the patients was found to have a 5 basepair long deletion in the probe, localized in the gene $C D K N 2 A$ p $14 \AA^{A R F}$ promoter region $1062 \mathrm{bp}$ in direction 5' from exon $1 \beta$ start codon of gene CDKN2A. After data had been normalised, the ratio of the absolute fluorescent signal of the probe to reference zone signals was less than $0.5(0.44)$, which indicates deletion in heterozygous state. 

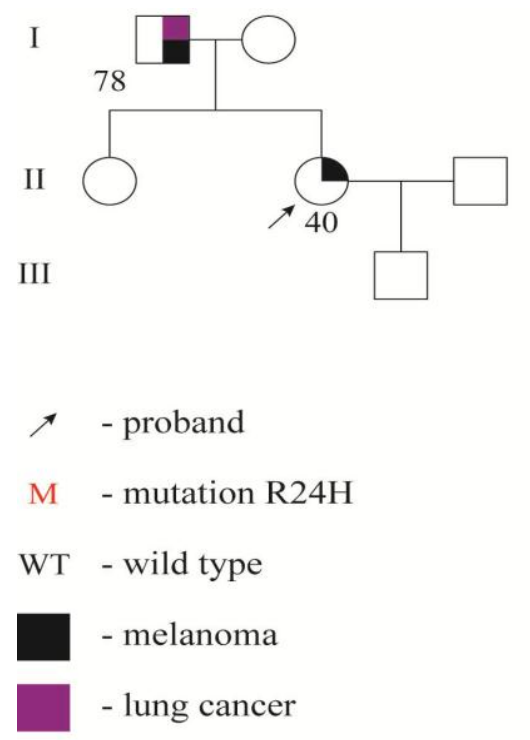

40 g. - age of primary melanoma onset

B

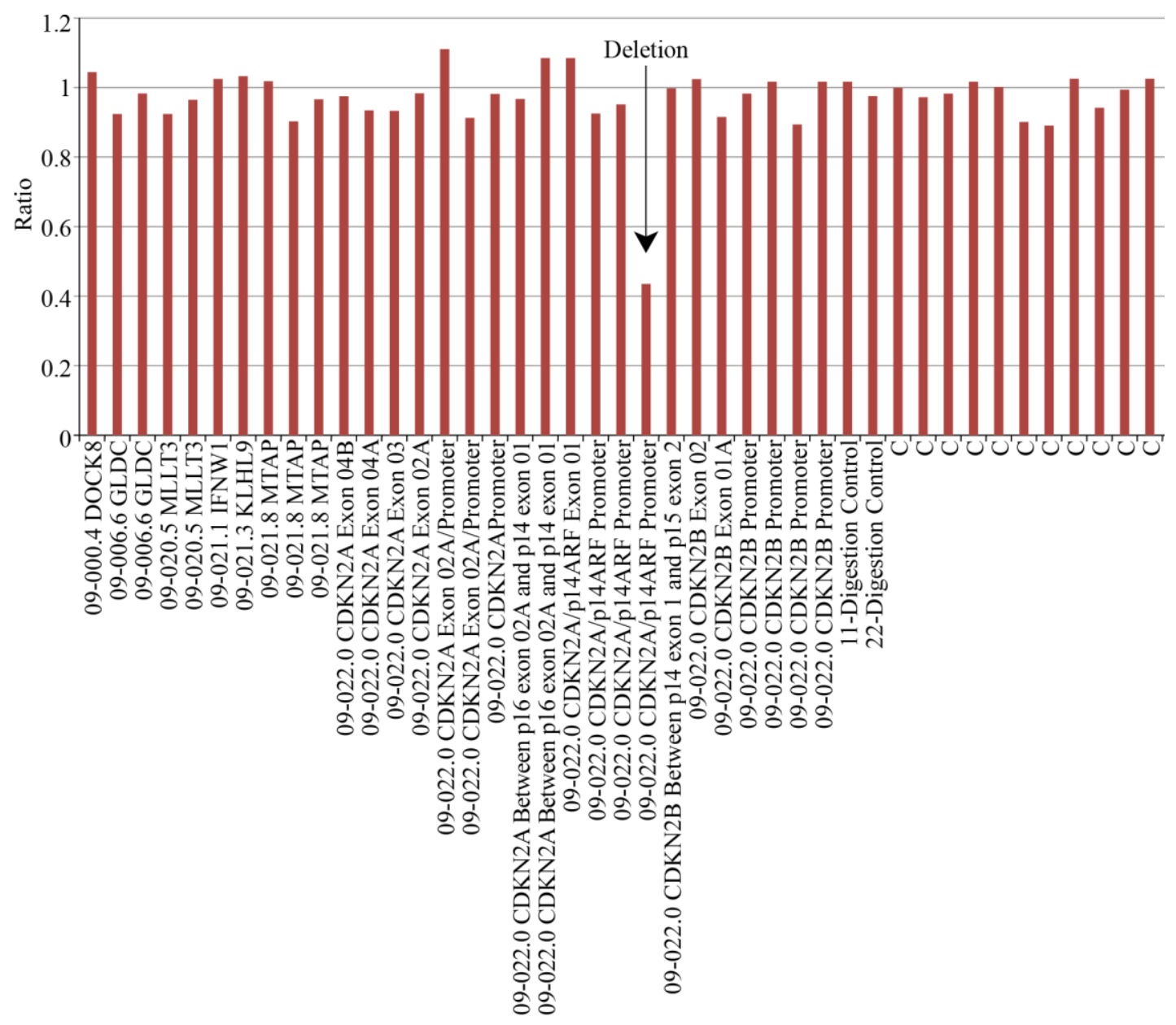

Figure 4.9 (A) Family tree of melanoma patient with the detected deletion in gene CDKN2A/p14 ${ }^{A R F}$ promoter region); (B) results of MLPA analysis of gene $C D K N 2 A / p 14^{A R F}$ promoter region 
The detected 5 base-pair deletion (c.-20676_- 20682delGTACG) in the $C D K N 2 A$ p $14{ }^{A R F}$ promoter region is the first mutation in gene $C D K N 2 A$ that has been detected among Latvian melanoma patients with a family history of melanoma (Fig 4.9 (B)).

The patient was a woman with melanoma diagnosed on the abdomen at the age of 40. The patient has skin type I, fair hair and blue eyes, and a large number of moles, as well as lentigo solaris on her face and body. Histologically the melanoma was pigmented, with no ulceration, of $10 \mathrm{~mm}$ Breslow depth and Clark level III. The patient's family history revealed one other melanoma case. The patient's father has been diagnosed with two tumors, i.e. histologically confirmed skin melanoma (age at primary diagnosis: 78 years) and a lung tumor. The mean age at which melanoma was diagnosed in the family was 59 years (Fig. 4.9(A)).

\subsubsection{Mutations in high-risk melanoma susceptibility genes $C D K N 2 A$ and CDK4 in patients with multiple primary melanomas}

From all the patients included in genetic analysis 4 patients with multiple primary melanomas were singled out as a separate group. The encoding part of gene CDKN2A and its adjacent sequences, as well as exon 2 of gene CDK4 was analysed in this group of patients. No mutations were found in the encoding part of gene CDKN2A and its adjacent areas. Two of the patients were found to have polymorphism c.*69C>T (rs3088440) in the 3' untranslated region of gene CDKN2A. Similarly, mutations were also absent in exon 2 of gene $C D K 4$.

\subsubsection{Mutations in high-risk melanoma susceptibility genes $C D K N 2 A$ and $C D K 4$ in younger melanoma patients}

A separate analysis of 47 younger patients diagnosed with melanoma was conducted (age $\leq 40$ at the time of diagnosis). Gene $C D K N 2 A$ mutations were analysed, including in the encoding part and adjacent sequences ( $1 \alpha, 1 \beta$, exons 2 and 3). Gene CDK4 exon 2 mutations were also analysed. The mean age of patients included in this group was 32.9 years, median 33 years. No mutations were detected in gene $C D K N 2 A$. The three polymorphisms detected during previous analyses, i.e. c.442G>A (Ala148Thr) (rs3731249) in exon 2, c. ${ }^{* 29 G}>\mathrm{C}(\mathrm{rs} 11515)$ and c. ${ }^{* 69 C}>\mathrm{T}(\mathrm{rs} 3088440)$ in the 3 , untranslated region of the gene, were identified. Exon 2 of gene CDK4 was sequenced for all 47 patients of the younger age group. No mutations were found except in one 
patient (M268). The latter was a woman aged 33 with 4 other melanoma cases in family history and. the results of analysis have been described above.

\subsubsection{The role of $M C 1 R$ polymorphisms in melanoma development}

Gene MC1R polymorphisms were analysed in 200 melanoma patients with comprehensive information about their respective pigmentation phenotypes. The control group included 200 healthy subjects with no diagnosed melanoma or other tumor types. The control group was set up to correspond to the patient group by age and by gender.

In total, $71 \%$ (284 from 400) of the individuals analysed showed a total of 26 different polymorphisms of gene MC1R. Polymorphisms were found in $159(79.5 \%)$ of the melanoma patients and in $125(62.5 \%)$ of the control subjects. From the 26 polymorphisms detected 18 were non-synonymous, 7 were synonymous and 1 was an insertion (Table 4.4). Two of the detected polymorphisms were novel. These were the polymorphisms Val165Ileu (found in a control subject) and Val188Ileu (found in a melanoma patient). The expected impact of both polymorphisms on receptor functions was tested with the PolyPhen-2 software. The analysis showed that neither Val165Ileu, nor Val188Ileu had a significant impact on receptor functional activity.

Four of the nonsynonymous polymorphisms detected (Val60Leu, Val92Met, Arg151Cys and Arg160Try) were more frequent in melanoma patients than in control subjects, and these differences were statistically significant, indicating that the respective polymorphisms in the population of Latvia are associated with a higher melanoma development risk (Table 4.4).

The relationship between the number of polymorphisms per individual and the risk of developing melanoma was analysed, and the analysis indicated that with a higher number of polymorphisms there was a growing risk of developing melanoma. The presence of a single non-synonymous polymorphism increased the risk of developing melanoma almost two times $(\mathrm{OR}=1.98 ; 95 \%$ CI 1.26-3.11; $\mathrm{p}=0.003)$, whereas two or more polymorphisms increased the risk almost fourfold (OR=3.98; 95\% CI 2.14 - 7.38; $\mathrm{p}<0.001)$. Consistently with the above, comparison of melanoma patients and control subjects with at least one polymorphism showed that the presence of a polymorphism as such is also related to a higher risk of developing melanoma $(\mathrm{OR}=2.36$; 95\% CI 1.53 $3.63 ; \mathrm{p}<0.001)$. 
Table 4.4

Polymorphism frequency of the MC1R gene of melanoma patients and control persons

\begin{tabular}{|c|c|c|c|c|c|c|c|c|}
\hline \multirow[t]{2}{*}{$\begin{array}{l}\text { Nucleotid } \\
\text { change }\end{array}$} & \multirow[t]{2}{*}{$\begin{array}{l}\text { Amino acid } \\
\text { change }\end{array}$} & \multicolumn{2}{|c|}{$\begin{array}{c}\text { Melanoma } \\
\text { patients } \\
(\mathbf{n}=\mathbf{2 0 0})\end{array}$} & \multicolumn{2}{|c|}{$\begin{array}{l}\text { Control } \\
\text { persons } \\
(\mathrm{n}=200)\end{array}$} & \multirow[t]{2}{*}{ OR } & \multirow[t]{2}{*}{$95 \% \mathrm{CI}$} & \multirow[t]{2}{*}{$\mathbf{p}$} \\
\hline & & $\mathbf{n}$ & $(\%)$ & $\mathrm{n}$ & $(\%)$ & & & \\
\hline Wt & - & 41 & (20.5) & 75 & (37.5) & 1 & reference & - \\
\hline \multicolumn{9}{|c|}{ Nonsynonimous } \\
\hline g.133T >C & Phe45Leu & 0 & $(0)$ & 1 & $(0.5)$ & - & - & - \\
\hline g. $178 \mathrm{G}>\mathrm{T}$ & Val60Leu & 23 & $(11.5)$ & 12 & $(6.0)$ & 3.51 & $1.58-7.76$ & 0.001 \\
\hline g. $248 \mathrm{C}>\mathrm{T}$ & Ser83Leu & 2 & $(1.0)$ & 0 & $(0)$ & - & - & - \\
\hline g. $252 C>A$ & Asp84Glu & 1 & $(0.5)$ & 0 & $(0)$ & - & - & - \\
\hline g. $265 \mathrm{G}>C$ & Gly89Arg & 0 & (0) & 1 & $(0.5)$ & - & - & - \\
\hline g. $274 \mathrm{G}>A$ & Val92Met & 51 & $(25.5)$ & 34 & $(17.0)$ & 2.74 & $1.54-4.89$ & $<0.001$ \\
\hline g. $284 C>T$ & Thr95Met & 1 & $(0.5)$ & 0 & $(0)$ & - & - & - \\
\hline g. $363 C>G$ & Asp121Glu & 1 & $(0.5)$ & 1 & $(0.5)$ & 1.83 & $0.11-30,02$ & 0.668 \\
\hline g. $425 \mathrm{G}>A$ & Arg142His & 8 & $(4.0)$ & 8 & $(4.0)$ & 1.83 & $0.64-5.23$ & 0.255 \\
\hline g. $451 \mathrm{C}>\mathrm{T}$ & Arg151Cys & 35 & $(17.5)$ & 14 & $(7.0)$ & 4.57 & $2.21-9.47$ & $<0.001$ \\
\hline g. $456 C>A$ & Tyr152X & 1 & $(0.5)$ & 0 & (0) & - & - & - \\
\hline g. $464 \mathrm{~T}>\mathrm{C}$ & Ile155Thr & 13 & $(6.5)$ & 14 & $(7.0)$ & 1.70 & $0.73-3.96$ & 0.216 \\
\hline g. $478 \mathrm{C}>\mathrm{T}$ & Arg160Try & 49 & $(24.5)$ & 35 & $(17.5)$ & 2.56 & $1.44-4.56$ & 0.001 \\
\hline g. $488 \mathrm{G}>A$ & Arg163Gln & 16 & $(8.0)$ & 15 & $(7.5)$ & 1.95 & $0.88-4.35$ & 0.099 \\
\hline g. $493 \mathrm{G}>\mathrm{A}$ & Val165Ileu & 0 & (0) & 1 & $(0.5)$ & - & - & - \\
\hline g.550G $>C$ & Asp184His & 0 & $(0)$ & 1 & $(0.5)$ & - & - & - \\
\hline g. $562 \mathrm{G}>\mathrm{A}$ & Val188Ileu & 1 & $(0.5)$ & 0 & $(0)$ & - & - & - \\
\hline g. $637 C>T$ & Arg213Try & 0 & $(0)$ & 1 & $(0.5)$ & - & - & - \\
\hline \multicolumn{9}{|l|}{ Synonimous } \\
\hline g.399C $>\mathrm{T}$ & Cys133Cys & 1 & $(0.5)$ & 0 & $(0)$ & - & - & - \\
\hline g. $453 \mathrm{C}>\mathrm{G}$ & Arg151Arg & 1 & $(0.5)$ & 0 & $(0)$ & - & - & - \\
\hline g. $498 \mathrm{G}>A$ & Ala166Ala & 1 & $(0.5)$ & 0 & $(0)$ & - & - & - \\
\hline g. $699 \mathrm{G}>A$ & Gln233Gln & 2 & (1.0) & 2 & $(1.0)$ & 1.83 & $0.25-13.47$ & 0.548 \\
\hline g. $819 \mathrm{C}>\mathrm{T}$ & Cys273Cys & 0 & $(0)$ & 1 & $(0,5)$ & - & - & - \\
\hline g. $942 A>G$ & Thr314Thr & 64 & $(32.0)$ & 53 & $(26.5)$ & 2.21 & $1.30-3.74$ & 0.003 \\
\hline g. $948 \mathrm{C}>\mathrm{T}$ & Ser316Ser & 7 & $(3.5)$ & 7 & $(3.5)$ & 1.83 & $0.60-5.58$ & 0.283 \\
\hline \multicolumn{9}{|l|}{ Insertion } \\
\hline g.496insG & ins166 & 0 & $(0)$ & 1 & $(0.5)$ & - & - & - \\
\hline
\end{tabular}

$\mathrm{p}$ - statistical significance, $\mathrm{OR}$ - odds ratio, CI - confidence interval, $\mathrm{Wt}$-wild type

A similar relationship was seen when gene $M C 1 R$ polymorphisms were grouped depending on their link with the so called RHC "red hair colour" phenotype, i.e. when all the RHC polymorphisms (Asp84Glu, Arg151Cys and Arg160Try) were grouped together and compared to the group of all other non-synonymous (NRHC) polymorphisms; the relationship also depended on whether the polymorphism belonged to one group or the other. Individuals with two RHC polymorphisms have the highest 
risk of melanoma $(\mathrm{OR}=7.15 ; 95 \% \mathrm{CI}$ : 0.78-65.84, $\mathrm{p}=0.045)$. Individuals with two NRHC polymorphisms $(\mathrm{OR}=4.17 ; 95 \% \mathrm{CI}$ : 1.50-11.57, $\mathrm{p}=0.004)$ or one RHC and one NRHC polymorphism $(\mathrm{OR}=3.69 ; 95 \% \mathrm{CI}: 1.81-7.53, \mathrm{p}<0.001)$ have also a high melanoma risk. Moreover, the presence of one RHC and one NRHC polymorphism increases the risk of melanoma 1.4 times as compared to the presence of just one RHC polymorphism $(\mathrm{OR}=2.57 ; 95 \% \mathrm{CI}: 1.45-4.57, \mathrm{p}=0.001)$. A slightly increased risk of melanoma was observed also for individuals with one NRHC polymorphism $(\mathrm{OR}=$ 1.67; $95 \%$ CI: 1.01-2.77, $\mathrm{p}=0.046)$ (Table 4.5).

Table 4.5

\section{Association between RHC and NRHC polymorphisms and melanoma risk}

\begin{tabular}{|c|c|c|c|c|c|c|c|}
\hline \multirow[t]{2}{*}{$\begin{array}{c}M C 1 R \\
\text { polymorphisms }\end{array}$} & \multicolumn{2}{|c|}{$\begin{array}{c}\text { Melanoma } \\
\text { patients } \\
(\mathbf{n}=\mathbf{2 0 0})\end{array}$} & \multicolumn{2}{|c|}{$\begin{array}{c}\text { Control persons } \\
(\mathbf{n}=\mathbf{2 0 0})\end{array}$} & \multirow[t]{2}{*}{$\mathbf{R}$} & \multirow[t]{2}{*}{$95 \%$ CI } & \multirow[t]{2}{*}{$\mathbf{p}$} \\
\hline & $\mathbf{n}$ & $\%)$ & $\mathbf{n}$ & $(\%)$ & & & \\
\hline WT & 47 & 23.5 & 84 & 42.0 & 1 & reference & - \\
\hline $1 \mathrm{RHC}$ variant & 46 & 23.0 & 32 & 16.0 & 2.57 & $1.45-4.57$ & $<0.001$ \\
\hline 2 RHC variants & 4 & 2.0 & 1 & 0.5 & 7.15 & $0,78-65.84$ & 0.045 \\
\hline $1 \mathrm{NRHC}$ variant & 58 & 29.0 & 62 & 31.0 & 1.67 & $1.01-2.77$ & $<0.046$ \\
\hline $2 \mathrm{NRHC}$ variants & 41 & 7.0 & 6 & 3.0 & 4.17 & $1.50-11.57$ & 0.004 \\
\hline $\begin{array}{l}1 \mathrm{RHC} \text { and } \\
1 \mathrm{NRHC} \text { variant }\end{array}$ & 31 & 15.5 & 15 & 7.5 & 3.69 & $1.81-7.53$ & $<0.001$ \\
\hline
\end{tabular}

RHC polymorphisms: D84E, R151C, R160W; NRHC - other nonsynonimous polymorphisms

Since $M C 1 R$ gene polymorphisms have been showed to relate to the individual's pigmentation phenotype, i.e. hair and eye colour as well as skin type, the next step of the study was to check how the seven most frequently encountered gene MCIR polymorphisms (Val60Leu, Val92Met, Arg142His, Arg151Cys, Ile155Thr, Arg160Try, Arg163Gln) were related to the pigmentation phenotypes in the control group. The control subjects were divided into groups according to their pigmentation phenotype: red/fair and brown/black hair, blue/grey and green/brown/other eyes, I/II and III/IV skin type, a large number/ a few freckles and few/no freckles and a large number/a few nevi and few/no nevi.

The polymorphisms Val92Met, Arg151Cys and Arg160 were linked to red/fair hair colour, skin type I/II and an increased number of freckles. The polymorphisms Val60Leu and Ile155Thr were linked to skin type and freckles, whereas polymorphism $\operatorname{Arg} 142 \mathrm{His}$ is linked to hair colour only. Pigmentation phenotype was not influenced by 
polymorphism Arg163Gln. Similarly, gene MCIR polymorphisms were not related to the number of nevi and eye colour. Individuals with at least one polymorphism more than two times as frequently had red or fair hair $(\mathrm{OR}=2.52 ; 95 \%$ CI 1.37-4.67; $\mathrm{p}=0.003)$ and almost 4 times as frequently had skin type I or II $\quad(\mathrm{OR}=3.94 ; 95 \% \mathrm{CI}$ $1.55-10.05 ; \mathrm{p}=0.002)$ and a comparatively high number of freckles $(\mathrm{OR}=3.94 ; 95 \% \mathrm{CI}$ 1.55-10.05; $\mathrm{p}=0.002$ ). Similarly as in the case of separate polymorphisms, no relationship between the number of gene $M C 1 R$ polymorphisms and the amount of freckles was established in the case of multiple polymorphisms. No relationship was detected between eye colour and number of polymorphisms either.

Similarly to the control subjects described above, the melanoma patients were also subdivided into groups depending on their pigmentation phenotype. After stratification, the impact of polymorphisms on development of melanoma could be observed only in the relatively low-risk phenotype groups, i.e. individuals with dark hair, skin type III/IV and a small amount of freckles. Similarly to what has been described before, there was a relationship between the number of polymorphisms and the degree of risk for developing melanoma. For individuals with dark hair, the presence of at least one polymorphism increased the risk of melanoma more than twofold $(\mathrm{OR}=2.70 ; 95 \%$ CI 1.49-4.88; $\mathrm{p}<0.001)$. The melanoma risk, in the presence of two polymorphisms, is increased more than twofold also for those individuals who have skin type III or IV (OR=2.80; 95\% CI 1.64-4.78; $\mathrm{p}=<0.001)$, and the same can be observed for individuals with a small amount of freckles $(\mathrm{OR}=2.61 ; 95 \%$ CI 1.61-4.21; $\mathrm{p}=<0.001)$. Moreover, in all three of the abovementioned groups the presence of two polymorphisms is associated with a risk almost two times higher than in the case of only one polymorphism. On the other hand, no such relationship has been observed for eye colour and amount of nevi.

Grouping of gene MC1R polymorphisms into RHC and NRHC polymorphisms led to similar results. Individuals with dark hair have a two times higher risk of melanoma if they have both NRHC polymorphisms (OR=2.53; 95\% CI 1.31-4.88; $\mathrm{p}=0.005)$ and $\mathrm{RHC}$ polymorphisms $(\mathrm{OR}=2.26 ; 95 \%$ CI 0.96-5.30; $\mathrm{p}=0.059)$. Though in the case of RHC polymorphisms the results do not fulfil the criteria for statistical significance, they come close to values that are statistically significant. The melanoma risk is highest, if an individual has both RHC and NRHC polymorphisms ( $O R=4.70$; 95\% CI 1.65-13.38; $\mathrm{p}=0.002$ ). However, for individuals of sin type III and IV the risk is highest in the presence of RHC polymorphisms (OR=3.39; 95\% CI 1.66-6.94; $\mathrm{p}<0.001)$. 
Similarly, the risk of melanoma becomes more than 3 times higher in the presence of a RHC polymorphism in combination with a NRHC polymorphism $(\mathrm{OR}=3.25 ; 95 \% \mathrm{CI}$ 1.32-8.01; $\mathrm{p}=0.008)$. There is a slightly lower risk only in the case of NRHC polymorphisms $(\mathrm{OR}=2.44 ; 95 \% \mathrm{CI} 1.35-4.44 ; \mathrm{p}=0.003)$. A similar situation is observed for individuals with a small amount of freckles, except that in this case the highest risk is linked with a combination of RHC and NRHC polymorphisms (OR=3.26; 95\% CI 1.39-7.65; $\mathrm{p}=0.005)$, followed by RHC polymorphisms $(\mathrm{OR}=3.16 ; 95 \%$ CI 1.65-6.05; $\mathrm{p}<0.001)$ and NRHC polymorphisms $(\mathrm{OR}=2.23 ; 95 \%$ CI 1.30-3.82; $\mathrm{p}=0.003)$. As in above, similar relationships are not observed for nevi and eye colour. 


\section{DISCUSSION}

Our study showed a significant increase in melanoma incidence in Latvia from 1998 until 2008. In several international studies the mean age at the time of diagnosis has been shown to lie between 53.7 and 59.0 years gadiem [Geller et al., 2002, Ferrari et al., 2008, Biau et al., 2007, Chamberlain et al., 2003]. The mean age at the time of melanoma onset in our study was 61.3 years, thus higher. This could be explained by the fact that melanoma patients in Latvia are generally diagnosed at later stages, which would also explain the comparatively worse survival rates. Our data indicates better survival rates for females despite the fact that the mean age at the time of diagnosis was higher in females than in males.

Similar to other studies we found that the most frequent localisation of the tumor was the trunk in males and legs in females [Lipsker et al., 2007; Liang et al., 2010]. Several studies have also showed that the head and the neck are the frequent localisations for the tumor in males but we could not approve that in our study. However we have shown the predominace of the head and neck melanoma in elderly patients. Survival rates respective to the tumour localisation have been shown worse in males compared to females [Kienstra et al., 2005; Zettersten et al., 2003]. In our study, we have approved this only for males diagnosed with melanoma on their limbs.

It has been previously shown that melanoma patients tend to develop a second primary melanoma, however only $0.5 \%$ of the patients in our study developed a second primary melanoma. This number is low compared to other studies [Bower et al., 2010; Titus-Ernstof et al., 2006; Levi et al., 2005; Goggins et al., 2003, Ferrone et al., 2005; Nashan et al., 2003] reporting the incidence rate of multiple primary melanomas to lie between 0.5 and $8.6 \%$.

According to several authors [Garbe et al., 209; Payette et al., 2009; Arora et al., 2009; Lens et al., 2004], superficial spreading melanoma is the most frequent histopathologic tumour subtype. In our study, nodular tumors were the most frequent subtype, showing worse survival rates when compared to superficial spreading melanoma.

Our findings underline the importance of Breslow thickness and ulceration for the course of the disease. An increase in tumour depth correlates with a poorer prognosis and is one of the most important prognostic factors for melanoma [Markovic et al., 2007]. Although the mean Breslow thickness has declined between 1998 and 
2008, the median tumour thickness has not changed over time and is significantly high $(6.00 \mathrm{~mm})$ when compared to other European countries where the mean thickness of melanoma is $0.80-2.24 \mathrm{~mm}$ [Liang et al., 2010; Linos et al., 2009, Barbe et al., 2011]. We confirmed significantly higher survival rates for patients without ulcerated melanomas. Patients with tumour ulceration, especially males, have worse survival rates than patients of the same gender but without ulceration. Amelanotic melanomas comprised $9.6 \%$ of all melanoma cases, which is slightly more than the reported rates lying between $1.8 \%$ and $8.1 \%$ [Gualandri et al., 2009; Juliano et al., 1982]. Patients with pigmented melanomas had a better survival rate than patients with amelanotic tumours. In our study the number of nodular, thick and ulcerating tumors was higher in the patients of the senior age group above 63 years of age, which is true also for other populations [Balch et al., 2001].

Our study showed a steady increase in melanoma incidence in Latvia with a high percentage of delayed tumors. It was shown that this delay also lead to a poor survival prognosis. In order to develop earlier melanoma diagnostics in Latvia, more attention will need to be paid to educational campaigns, development of melanoma prevention programs and a better cooperation between general practitioners and dermatologists.

Despite continued research efforts, there is only partial awareness of the molecular mechanisms causing development of the disease. Most of the incidences of melanoma are sporadic, yet in about one tenth of all the cases melanoma is observed as an inherited genetic condition [de Snoo et al., 2005]. The main high-risk melanoma susceptibility gene identified where mutations have predominantly been found (20-40\% of cases) in melanoma prone families is the gene CDKN2A [Hansen et al., 2004]. Until now, analysis of gene $C D K N 2 A$ in Latvia has established polymorphisms with no proved relationship to development of melanoma (c.-33G>C; c.442G>A (Ala148Thr); c. ${ }^{*} 29 \mathrm{G}>\mathrm{C}$; c. $* 69 \mathrm{C}>\mathrm{T}$ ), while no mutations related to a predisposition to the disease have been detected [Pjanova et al., 2003, 2006, 2007]. On account of the negative result obtained, the present study in addition to the encoding part of the gene analysed also gene promoters and introns in patients with a family history of melanoma. On a global scale mutations related to a predisposition towards melanoma have been found in these regions, but in Latvia changes in these regions in melanoma patients had not been analysed before. There are relatively few melanoma patients with an established family history of melanoma in Latvia, approximately $8.8 \%$, and up to know only three 
melanoma patients with a family history of three and more cases of melanoma have been identified in Latvia.

Similarly as before, the patients with a family history of melanoma, pancreatic tumor or central nervous system tumor were found to have no mutations in the encoding part of gene $C D K N 2 A$. No gene $C D K N 2 A$ mutations were also detected in patients with multiple primary melanomas and young melanoma patients.

Since no mutations were found in the encoding part of gene $C D K N 2 A$ where gene mutations tend to be found most frequently, the $C D K N 2 A / p 16^{I N K 4 a}$ promoter was analysed in the patients with a family history of melanoma, pancreatic and brain tumor. The analysis detected only three different polymorphisms, i.e. c. $-191 \mathrm{~A}>\mathrm{G}$, c.-493A>T, and c. $-735 \mathrm{G}>\mathrm{A}$ which had been previously described in other studies [Harland et al., 2000; Pollock et al., 2001; Bisio et al., 2010] and shown to have insignificant differences between allele frequencies in melanoma patients and control subjects [Harland et al., 2000], indicating that they were not related to melanoma development. Apart from promoter analysis, intron 1 and 2 of gene $C D K N 2 A$ was also analysed in these patients. Two of the seven polymorphisms detected (IVS1+1569T>A; IVS2+82C $>\mathrm{T}$ ) are new variants of the sequence, that have not been previously described. The melanoma development related mutations detected in introns by other authors have an impact on splicing, for example IVS2+1G>T [Loo et al., 2003], c.147A $>$ C [Loo et al., 2003], D153spl (c.457G > T) [Rutter et al., 2003] and IVS1-1G>C [Petronzelli et al., 2001]. Examination of the DNA sequences adjacent to both of the new sequence variants did not reveal a splice site resulting from the change, which most probably means that both changes might be polymorphisms without any significant impact on development of melanoma.

On a global scale in separate melanoma prone families large deletions that may not be identified by direct sequencing have been detected. Therefore, the present study applied MLPA to analyse locus $9 p 21$ where gene $C D K N 2 A$ is located. The analysis revealed one patient with deletion in the probe localized in the gene $C D K N 2 A / p 14^{A R F}$ promoter region. For the first time a mutation in gene $C D K N 2 A$ was established in a melanoma patient in Latvia. On a global scale the identified deletions covering this region are very large and extend over several kilo base-pairs [Mistry et al., 2005; Randerson-Moor et al., 2001; Bahuau et al., 1997; Pasmant et al., 2007; Laud et al., 2006]. The identified deletion of 5 base-pairs is not similar to the deletions described before in this region, since it is comparatively small. The promoter region of gene 
$\mathrm{CDKN} 2 \mathrm{~A} / p 14^{A R F}$ contains several potential transcription factor binding sites [Robertson et al., 1998]. Thus, a deletion localized in the $C D K N 2 A / p 14^{A R F}$ promoter region may derange normal promoter structure, which may negatively affect binding with transcription factors and, thus, prevent proper functioning of the cell cycle regulatory mechanism. However, the specific impact of the detected deletion on protein p14ARF expression may be determined solely through functional studies, which we were not a target for the present study. It is also hardly possible to be sure whether the detected deletion is related to inheritance of melanoma in the family, since its segregation for the disease could not be checked due to the fact that the patient's father who had been diagnosed with melanoma had already died.

The other high-risk melanoma susceptibility gene identified is gene $C D K 4$. The families where inheritance of melanoma is related with mutations in this gene do not differ in phenotype from those with gene CDKN2A mutations [Goldstein et al., 2000]. However, mutations in this gene are very rare: on a global scale only 10 families with mutation in this gene have been described. To date, gene CDK4 mutations have been detected only in codon 24 , localised in exon 2. In Latvia, however, a total of 3 families with gene CDK4 mutation $\mathrm{R} 24 \mathrm{H}$ have been described. This is a significant finding, given the small number of $C D K 4$ mutation positive families worldwide.

The mean age of all the analysed patients with gene $C D K 4$ mutation $\mathrm{R} 24 \mathrm{H}$ at the time of primary diagnosis of melanoma was 39.6 years, median 42 years. Comparison to the mean age (61.3 years and age median 63.4 years) of the patient group treated at RAKUS LOC from 1998 to 2008 predominantly with sporadic melanoma or to the mean age (52.6 years and age median 54.0 years) of the patient group in which gene $M C I R$ was analysed and who predominantly had sporadic melanoma shows that the gene $C D K 4$ mutation $\mathrm{R} 24 \mathrm{H}$ positive patients have developed melanoma and had it diagnosed at a significantly younger age as compared to the sporadic melanoma cases, as confirmed also in other studies [Molven et al., 2005]. In turn, comparison of families with mutations in gene $C D K 4$ shows that the mean age of incidence (39.6 years) and median (42 years) in Latvian families is slightly higher than in the CDK4 mutation positive families (34 years) identified in the US [Goldstein et al., 2000], but similar to a Norwegian family - 41 years [Molven et al., 2005]. This might be related to similar climatic conditions in Latvia and Norway or differences in low susceptibility modification genes [Hayward, 2003]. In Latvia there is also a lower average number 
(1.6) of skin melanoma per $C D K 4$ mutation positive patient in all the three families compared to the Norwegian family (2.2) and the American families (2.4) [Molven et al., 2005]. The comparatively fewer cases of melanoma in our families may, perhaps, be explained by lack of information on other family members. Family haplotype analysis showed that two of the identified melanoma prone families in Latvia which were gene CDK4 mutation $\mathrm{R} 24 \mathrm{H}$ positive might have a common distant ancestor, which furthermore might set them apart from the other $C D K 4$ mutation $\mathrm{R} 24 \mathrm{H}$ positive families. It could be also claimed that the gene $C D K 4$ mutation $\mathrm{R} 24 \mathrm{H}$ is a founder mutation in the Latvian population.

The overall results obtained show that mutations in the known high-risk melanoma susceptibility genes $C D K N 2 A$ and $C D K 4$ do not account for the Latvian melanoma families with two melanoma cases. Only one of the analysed patients with a family history of two melanoma cases was shown to have a change in gene $C D K N 2 A$, which might potentially be seen as a mutation related to the condition. Therefore, there is a chance that the melanoma cases in families with two incidences are predominantly of sporadic origin and are not related to mutations in melanoma susceptibility genes. This is further evidenced by the clinical descriptions of the patients which do not differ significantly from the descriptions of sporadic melanoma patients. This explanation, however, is of limited credibility due to the low overall incidence of melanoma in Latvia. It is also possible that the mutations are not manifest in the phenotypes of the mutation positive individuals, given the absence of high UV radiation levels in Latvia, which is one of the main environmental factors increasing mutation penetrance. Such an explanation would be coherent with the previously established relationship between higher penetrance of gene $C D K N 2 A$ mutations and higher UV radiation levels, for example in Australia and the USA [Bishop et al., 2002]. Mutations in other genes, for example, $M C 1 R$, or other yet unidentified melanoma susceptibility genes could serve as yet another explanation. During the past years many authors have been pursuing genome wide association studies (GWAS) to find other genes with mutations segregated with melanoma prone families as it is in case of gene $C D K N 2 A$. The broadest of these studies in the framework of the International Melanoma Genetics Consortium (GenoMEL) has not revealed any significant new information about loci that might contain melanoma susceptibility genes. The previously known loci, which are encountered more frequently, have been shown to have the strongest relationship 
with the development of melanoma, while their total risk for the development of the disease has been shown to be lower [Bishop et al., 2009]. These results point to the possibility that there may be no other high-risk melanoma susceptibility genes similar to $C D K N 2 A$, while there might be a set of a number of interacting lower-risk genes accounting for genetic predisposition.

Given that mutations in genes $C D K N 2 A$ and $C D K 4$ are mainly observed in families with recurrent melanoma and are relatively very rare in the overall population [Berwick et al., 2006], the present study also included analysis of gene MCIR as a low penetrance melanoma susceptibility gene. Gene $M C I R$ is known to be extremely polymorphous, and the present study, too, detected 26 different gene polymorphisms from which four, i.e. Val60Leu, Val92Met, Arg151Cys and Arg160Try, were related to a higher melanoma development risk in the population of Latvia with a 2-4 times higher risk for polymorphism carriers. The risk was higher for individuals with dark hair and skin type III/IV.

Melanoma patients had polymorphisms more frequently than control subjects, i.e. $76.5 \%$ and $58.0 \%$ cases respectively. A similar ratio of polymorphisms between patients and controls has been observed also in Sweden [Gerstenblith et al., 2007] and Italy [Fargnoli et al., 2008]. In Germany, similarly to Latvia, gene MCIR polymorphisms have been found in $76 \%$ of patients, yet, unlike in Latvia, they have been detected also in $67 \%$ of the control subjects [Scherer et al., 2009]. On the other hand, in Poland and Spain gene MCIR polymorphisms are less frequently seen both in patients and in controls, i.e. 51\% vs. $45 \%$ respectively in Poland [Brudnik et al. 2008] and $66 \%$ vs. $52 \%$ in Spain [Scherer et al., 2009]. These facts point to a different role of gene MCIR in different populations.

Given the number of non-synonymous polymorphisms per individual, in the population of Latvia the very presence of a polymorphism is associated with a more than two times higher risk of melanoma $(\mathrm{OR}=2.36 ; 95 \% \mathrm{CI}=1.53-3.63 ; \mathrm{p}<0.001)$. Moreover, the presence of two or more polymorphisms is associated with a risk that is two times higher than in the case of a single polymorphism $(\mathrm{OR}=1.98 ; 95 \% \mathrm{CI}=1.26$ 3.,11; $\mathrm{p}=0.003$ and $\mathrm{OR}=3.98 ; 95 \% \mathrm{CI}=2.14-7.38 ; \mathrm{p}=<0.001)$. Similar trends of higher melanoma risk associated with a higher number of polymorphisms in an individual have been observed in other populations [Galore-Haskel et al., 2009; Scherer et al., 2009]. 
For melanoma, as for other oncological conditions, where genetic factors play a role, the patient's family history is crucially important. If the patient notes down melanoma incidence in his/her family, it would be valuable to document this information in the family tree format, which would make prevalence of the disease in the family easier understood and summarised. The patients with a family history of melanoma should consult a geneticist, who, if required, could offer them genetic examination. Individuals who should be advised to undergo genetic testing are: a) melanoma patients with melanoma among first-degree relatives; b) melanoma patients with two or more melanoma cases among their relatives; c) individuals with three or more melanoma cases among their relatives.

Some countries now offer genetic testing of gene CDKN2A variants for melanoma patients, for example, in populations with frequent founder mutations, e.g. in Italy [Bruno et al., 2009] and in the Netherlands [de Snoo et al., 2008]. Negative test results might, however, provide a false sense of relief for the individuals tested, given the fact that most of the genetic risk factors are not as yet understood. In Latvia the question is open to debate whether testing of gene $C D K N 2 A$ variants should be advised, given the fact that, unlike in other countries, in Latvia CDKN2A gene mutations are not that frequent. Detection of the very rare mutations in gene CDK4 in all the three melanoma prone families identified in the population of Latvia with a history of three and more melanoma cases is of unique significance. Unlike in other populations, potentially genetically predisposed melanoma patients in Latvia should be tested for the presence of mutation $\mathrm{R} 24 \mathrm{H}$ in gene $C D K 4$. The mutation positives have a high risk of melanoma; therefore, testing would be practically useful also for prevention. Gene $M C 1 R$ is extremely polymorphous and analysis of its variants as yet is unable to yield significant information for assessing the risk of melanoma. Therefore, the target genes for genetic testing of individuals with a family history of melanoma might be CDKN2A and $C D K 4$. The methodology for genetic testing of genes $C D K N 2 A(1 \alpha, 1 \beta$ and exon 2$)$ and $C D K 4$ (exon 2) has been finalised and included in the list of analysis offered by the Genome Centre. In view of the growing incidence of melanoma and potential genetic predisposition to melanoma, both patients and doctors should be informed on possibilities of genetic testing in case of recurrent melanoma in family history.

In view of the growing melanoma incidence indicators in Latvia, the population should be educated about the threat of melanoma, potential causes of its development, 
its appearance, the importance of self-examination and options for testing skin lesions (dermatoscopy). Special emphasis should be placed on the impact of excessive natural tanning, artificial tanning sunbeds and sunburn on development of melanoma, since intermittent exposure to intensive sun and heavy sunburn, especially below the age of 20, are the main risk factors for sporadic melanoma [Gandini et al., 2005; Bishop et al., 2002]. Individuals with gene $C D K N 2 A$ or $C D K 4$ mutations should have life-long protection from cumulative dosages of sun [Bishop et al., 2002].

Treatment prognoses are better, if melanoma is detected and removed at an early stage. A large part of melanomas are superficially spreading melanomas with a typical initial radial growth phase. Individuals with an increased melanoma development risk (patients or individuals with a family history of multiple cases of melanoma, pancreatic or CNS tumor, including individuals from gene $C D K N 2 A$ or $C D K 4$ mutation positive families, patients with multiple primary melanomas, young melanoma patients, patients with atypical birthmark syndrome and melanoma in family history) have to be trained in self-examination, timely recognition of changes in birthmarks and noticing new skin formations. High melanoma risk individuals require regular preventive examinations by a dermatologist 1 to 4 times a year depending on history and type of birthmarks [Marsden et al., 2010]. The birthmarks have to be examined dermatoscopically, and their digital images retained and analysed during repeat visits. 


\section{CONCLUSIONS}

1.1. In the period between 1998 and 2008 incidence of melanoma at RAKUS LOC increased from 3.3 in 1998 to 5.4 in 2008 ( $\mathrm{p}=0.003)$.

1.2. Melanoma patients were predominantly women, the ratio between women and men being 1:0.54; the most frequently seen location of melanoma in women was on their legs and in men on their trunk.

1.3. The mean age of melanoma patients was 63 years; no significant changes in patient age were observed over the period analysed.

1.4. The most frequently observed type of CMM was nodular melanoma with ulceration and average Breslow thickness of $6 \mathrm{~mm}$; Breslow thickness has been diminishing over time, yet it remains considerable.

2.1. Women compared to men have a higher life expectancy $(\mathrm{HR}=1.4 ; 95 \% \mathrm{CI}=1.1$ $1.7 ; \mathrm{p}=0.0018)$.

2.2. Life expectancy indicators correlate with Breslow thickness $(\mathrm{p}<0.001)$ and are lower in case of nodular melanoma and ulcerative melanoma.

3.1. Latvia typically has melanoma prone families with two cases of melanoma; families with three and more cases account for only $1 \%$ of the cases.4.1. Mutation c.71G>A $(\mathrm{R} 24 \mathrm{H})$ in exon 2 of gene $C D K 4$ has been established in three melanoma patients with a strong family history of melanoma (more than three melanoma cases in each family); the families are of the same mutation related haplotype according to microsatellite markers and SNPs, i.e. 113-194-CDK4-174201 and TAGG-102 respectively, which indicates a potential founder mutation in the population of Latvia.

4.2. Gene $C D K N 2 A$ analysis which covered both exon and gene $C D K N 2 A / p 16$ promoter and introns did not detect any mutations; all the changes detected were previously described gene polymorphisms or deep intronic changes with estimated low likelihood of influencing the gene encoded protein. 
4.3. A 5 base pair long deletion (c.-20676_- 20682delGTACG) was established in the promoter region of gene $\mathrm{CDKN} 2 \mathrm{~A} / p 14^{A R F}$, which is the first detected mutation in the $C D K N 2 A$ locus in melanoma patients with family history of melanoma in Latvia.

5.1. 26 different gene $M C 1 R$ polymorphisms have been found: 18 of them were nonsynonymous polymorphisms, 7 were synonymous polymorphisms and one was an insertion. Individually the gene $M C I R$ polymorphism with the strongest link to melanoma is Arg151Cys (OR=4.57; 95\% CI 2.21-9.47; p<0.001), followed by the polymorphisms Val60Leu $(\mathrm{OR}=3.51$; 95\% CI 1.58-7.76; $\mathrm{p}=0.001)$, Val92Met $(\mathrm{OR}=2.74 ; 95 \%$ CI 1.54-4.89; $\mathrm{p}<0.001)$ and Arg160Try $(\mathrm{OR}=2.56$; 95\% CI 1.444.56; $\mathrm{p}=0.001)$.

5.2. The risk of melanoma is associated with the number of gene $M C I R$ polymorphisms in an individual: the presence of one non-synonymous polymorphism increases the melanoma risk slightly more than two times $(\mathrm{OR}=2.36 ; 95 \%$ CI $1.53-3.63 ; \mathrm{p}<0.001)$, whereas the presence of two nonsynonymous polymorphisms increases the risk almost four times $(\mathrm{OR}=3.98 ; 95 \%$ CI 2.14-7.38; $\mathrm{p}<0.001)$.

5.3. In individuals with dark hair, skin type III/IV and no freckles the presence of gene $M C 1 R$ polymorphisms is associated with a higher melanoma development risk, whereas in individuals with fair hair, skin type I/II and freckles the presence of gene $M C 1 R$ polymorphisms is not associated with a higher risk and is likely to have an impact on the risk of developing melanoma through pigmentation. 


\section{REFERENCES}

1. Adzhubei I.A., Schmidt S., Peshkin L., et al. A method and server for predicting damaging missense mutations. Nature Methods 2010; 7: 248-249.

2. Arora A., Attwood J. Common Skin Cancers and Their Precursors. Surgical Clinics of North America 2009; 89: 703-712.

3. Balch C.M., Soong S.J., Gershenwald J.E., et al. 2001. Prognostic factors analysis of 17,600 melanoma patients: validation of the American Joint Committee on Cancer melanoma staging system. J Clin Oncol 2001; 19:3622-3634.

4. Balch C. M, Buzaid A. C. Soong S. J. et al. Final version of the American Join Committee on cancer staging system for cutaneous melanoma. J Clin Oncol 2001;19:3635-3648.

5. Barbe C., Hibon E., et al. Clinical and pathological characteristics of melanoma: a population based study in a French regional population. JEADV 2011; 26:159-164.

6. Berwick M., Orlow I., Hummer A., et al. The prevalence of CDKN2A germ-line mutations and relative risk for cutaneous malignant melanoma: an international population-based study. Cancer Epidemiol Biomarkers Prev. 2006 Aug;15(8):1520-5.

7. Biau D.J., Latouche A., Porcher R. Competing events influence estimated survival probability: when is Kaplan-Meier analysis appropriate? Clin Orthop Relat Res 2007; 462:229-33.

8. Bisio A., Nasti S., Jordan J. J., et al. Functional analysis of CDKN2A/p16INK4a 5'-UTR variants predisposing to melanoma. Hum Mol Genet. 2010 Apr 15; 19(8):1479-91.

9. Bishop D. T., Demenais F., Goldstein A. M., et al. Geographical variation in the penetrance of $C D K N 2 A$ mutations for melanoma. J. Natl. Cancer Inst. 2002; 94(12): 894903.

10. Bishop D.T., Demenais F., Iles M.M., et al. Genome-wide association study identifies three loci associated with melanoma risk. Nature Genetics 2009; 41: 920-928.

11. Box N. F., Duffy D. L., Chen W., Stark M., Martin N. G., Sturm R. A., Hayward N. K. MC1R genotype modifies risk of melanoma in families segregating CDKN2A mutations. The American Journal of Human Genetics 2001; 69: 765-773.

12. Bricca G.M., Brodland D. G., Ren D. et al. Cutaneous head and neck melanoma treated with Mohs micrographic surgery. Journal of the American Academy of Dermatology 2005; 52: 92-100.

13. Brown K. M., Macgregor S., Montgomery G. W., et al. Common sequence variants on 20q11.22 confer melanoma susceptibility. Nat Genet. 2008; 40(7): 838-840.

14. Brudnik U., Branicki W., Wojas-Pelc A., Kanas P. The contribution of melanocortin 1 receptor gene polymorphisms and the agouti signalling protein gene $8818 \mathrm{~A}>\mathrm{G}$ 
polymorphism to cutaneous melanoma and basal cell carcinoma in a Polish population. Experimental Dermatology 2008; 18: 167-174.

15. Carlson G. W., Murray D. R., Hestley A., et al. Sentinel lymph node mapping for thick (> or = 4-mm) melanoma: should we be doing it? Ann Surg Oncol. 2003; 10:408-415.

16. Casula M., Muggiano A., Cossu A., et al. Role of key-regulator genes in melanoma susceptibility and pathogenesis among patients from South Italy. BMC Cancer 2009; 9.

17. Chamberlain A. J., Fritschi L., Kelly J. W. Nodular melanoma: Patients' perceptions of presenting features and implications for earlier detection. J Am Acad Dermatol 2003; 48:694-701.

18. Debniak T., Scott R. J., Huzarski T., et al. CDKN2A common variants and their association with melanoma risk: a population-based study. Cancer Res. 2005 Feb 1; 65(3):835-9.

19. Debniak T., Scott R., Masojc B., et al. MC1R common variants, CDKN2A and their association with melanoma and breast cancer risk. International Journal of Cancer 2006; 119: $2597-2602$.

20. De Snoo F. A. Bishop D. T., Bergman W., et al. Increased risk of cancer other than melanoma in CDKN2A founder muation (p16-Leiden) - positive melanoma families. Clin Cancer Res 2008; 14(21):7151-7157.

21. den Dunnen J. T., Antonarakis S. E. Nomenclature for the description of human sequence variations. Human Genetics 2001; 109: 121-124.

22. Duffy D.L., Box N.F., Wei Chen, et al. Interactive effects of MC1R and OCA2 on melanoma risk phenotypes. Human Molecular Genetics 2004; 13: 447-461.

23. Fargnoli M.C., Spica T., Sera F., Pellecani G., Chiarugi A., Seidenari S., Carli P., Chimenti S., Peris K. Re: MC1R, ASIP, and DNA Repair in Sporadic and Familial Melanoma in a Mediterranean Population. Journal of the National Cancer Institute 2006; 98: 144-145.

24. Fargnoli M.C., Pike K., Pfeiffer R.M., et al. MC1R variants increase risk of melanomas harboring BRAF mutations. The Journal of Investigative Dermatology 2008; 128: 24852490.

25. Ferrone C. R., Ben Porat L., Panageas K. S. et al. Clinicopathological features of and risk factors for multiple primary melanomas. JAMA 2005;294:1647-1654.

26. Galore-Haskel G., Azizi E., Mohamdi H., et al. MC1R variant alleles and malignant melanoma risk in Israel. European Journal of Cancer;2009. 45: 2015 - 2022.

27. Gandini S., Sera F., Cattaruzza M. S et al. Meta-analysis of risk factors for cutaneous melanoma:III. Family history, actinic damage and phenotypic factors. Eur J Cancer 2005 Sep;41(14):2040-2059. 
28. Garbe C., Leiter U. Melanoma epidemiology and trends. Clinics in Dermatology 2009;27:3-9.

29. Geller A. C., Miller D. R., Annas G. D., et al. Melanoma incidence and mortality among US whites, 1969-1999. JAMA. Oct 9 2002; 288(14):1719-1720.

30. Gerstenblith M.R., Goldstein A.M., Fargnoli M.C., et al. Comprehensive evaluation of allele frequency differences of MC1R variants across populations. Human Mutation 2007; 28: 495-505.

31. Gerstenblith M.R., Shi J., Landi M.T. Genome-wide association studies of pigmentation and skin cancer: a review and meta-analysis. Pigment Cell \& Melanoma Research 2010; 23: 587-606.

32. Goggins W. B.,Tsao H. A populatio-based analysis of risk factors for a second primary cutaneous melanoma amng melanoma sirvivors. Cancer 2003;97:639-43.

33. Goldstein A. M., Struewing J. P., Chidambaram A., et al. Genotype-phenotype relationships in U.S. melanoma-prone families with CDKN2A and CDK4 mutations. Journal of the National Cancer Institute 2000; 92(12): 1006 - 1010.

34. Goldstein A.M., Landi M.T., Tsang S., et al. Association of MC1R variants and risk of melanoma in melanoma-prone families with CDKN2A mutations. - Cancer Epidemiology Biomarkers \& Prevention 2005;14: 2208-2212.

35. Goldstein A.M. Familial melanoma, pancreatic cancer and germline CDKN2A mutations. Hum Mutat 2004; 23:360.

36. Han J., Kraft P., Colditz G.A., et al. Melanocortin 1 receptor variants and skin cancer risk. - International Journal of Cancer 2006; 119: 1976-1984.

37. Hansen C.B., Wadge L.M., Lowstuter K., et al. Clinical germline genetic testing for melanoma. The Lancet Oncology 2004; 5(5): 314-319.

38. Harland M., Holland E.A., Ghiorzo P., et al. Mutation screening of the CDKN2A promoter in melanoma families. Genes Chromosomes Cancer 2000; 28(1):45-57.

39. Hayward N.K. Genetics of melanoma predisposition. Oncogene. 2003 May 19; 22(20):3053-62.

40. Juliano A.E., Cohran A.J., Moerton D.L. Melanoma from unknown primary site and amelanotic melanoma. Sem Oncol 1982; 9:442-447.

41. Kanetsky P.A., Rebbeck T.R., Hummer A.J., et al. Genes Environment and Melanoma Study Group. Population-Based Study of Natural Variation in the Melanocortin-1 Receptor Gene and Melanoma. Cancer Research 2006; 66: 9330-9337.

42. Kienstra M. A. Head and Neck Melanoma. Cancer Control 2005;12(4): 242-247

43. Kumar R., Smeds J., Berggren P., et al. A single nucleotide polymorphism in the 3'untranslated region of the CDKN2A gene is common in sporadic primary melanomas but mutations in the CDKN2B, CDKN2C, CDK4 and p53 genes are rare. Int J Cancer 2001 Nov 20; 95(6):388-93. 
44. Lens M.B., Dawes M. Global perspectives of contemporary epidemiological trends of cutaneous malignant melanoma. Br J Dermatol 2004; 150: 179-185.

45. Levi F., Randimbison L., Te V.C., La Vacehia C. High constant incidence rates of second cutaneous melanomas. Int J Cancer 2005;117:877-9.

46. Liang J. J, Robinson E., Martin R. C. Cutaneous melanom in New Zeland: 2000-2004. ANZ J Surg 2010; 80:312-316.

47. Linos E., Swetter S. M., Cockburn M. G., et al. Increasing burden of melanoma in the United States. 2009 Jul; 129(7):1666-74.

48. Lipsker D., Engel F., Cribier B. et al. Trends in melanoma epidemiology suggest three different types of melanoma. Br. J. Dermatol. 2007; 157:338-43.

49. Markovic S.N., Erckson L.A., Rao R.D., et al. Malignant melanoma in the 21st century, part 2:staging, prognosis, and treatment. Mayo Clin Proc 2007; 82(4):490-513.

50. Marsden J.R., Newton-Bishop J.A., Burrows L., et al. Revised U.K. Guidelines for the Management of Cutaneous Melanoma 2010. British Journal of Dermatology 2010; 163(2):238-256.

51. Martin R., Robinson E. Cutaneous melanoma in Caucasian New Zelanders: 1995-1999. Ast. N.Z.J.Surg. 2004; 74:233-7.

52. Mistry S.H.,Taylor C., Randerson-Moor J. A., et al. Prevalence of 9p21 deletions in UK melanoma families. Genes, Chromosomes and Cancer 2005 November; 44(3): 292-300.

53. Molven A., Grimstvedt M. B., Steine S.J., et al. A large Norwegian family with inherited malignant melanoma, multiple atypical nevi, and CDK4 mutation. Genes Chromosomes Cancer 2005; 44(1): 10-18.

54. Nashan D., Kocer B., Schiller M. et al.Significant risk of a second melanoma in patints with a history of melanoma but no further predisposing factors. Dermatology 2003;206:76-7.

55. Pasmant E., Laurendeau I., Héron D. et al. Characterization of a germ-line deletion, including the entire INK4/ARF locus, in a melanoma-neural system tumor family: identification of ANRIL, an antisense noncoding RNA whose expression coclusters with ARF. Cancer Research 2007; 67(8): 3963 - 3969.

56. Payette M. J., Katz M., Grant-Kels J. M. Melanoma prognostic factors found in the dermatopathology report. Clinics in Dermatology 2009;27:53-74.

57. Petronzelli F., Sollima D., Coppola G., et al. CDKN2A germline splicing mutation affecting both p16(ink4) and p14(arf) RNA processing in a melanoma/neurofibroma kindred. Cancer 2001 Aug; 31(4):398-401.

58. Pjanova D., Heisele O., Engele L., et al. Tumour suppressor gene CDKN2A/p16 germline mutations in melanoma patients with additional cancer and cancer in their family history. Acta Universitatis Latviensis 2003; 662: 25 - 32. 
59. Pjanova D., Heisele O., Engele L., et al. Analysis of Latvian melanoma families for $9 p 21$ germline deletions by the multiplex ligation-dependent probe amplification approach. Acta Universitatis Latviensis 2006; 710: 7-16.

60. Pjanova D., Engele L., Randerson-Moor J.A., et al. CDKN2A and CDK4 variants in Latvian melanoma patients: analysis of a clinic-based population. Melanoma research 2007; 17(3): 185-191.

61. Pollock P.M., Stark M.S., Palmer J.M., et al. Mutation analysis of the CDKN2A promoter in Australian melanoma families. Genes Chromosomes Cancer. 2001 Sep; 32(1):89-94.

62. Purcell S., Neale B., Todd-Brown K., et al. PLINK: a toolset for whole-genome association and population-based linkage analysis. American Journal of Human Genetics 2007; 81: 559-575.

63. Randerson-Moor J. A., Harland M., Williams S., et al. A germline deletion of p14(ARF) but not CDKN2A in a melanoma-neural system tumour syndrome family. Human Molecular Genetics 2001; 10(1): 55 - 62 .

64. Rutter J. L., Goldstein A. M., Dávila M. R., et al. CDKN2A point mutations D153spl(c.457G > T) and IVS2+1G>T result in aberrant splice products affecting both p16INK4a and p14ARF. Oncogene 2003; 22(28): 4444 - 4448.

65. Scherer D., Nagore E., Bermejo J.L., Figl A., et al. Melanocortin receptor 1 variants and melanoma risk: A study of 2 European populations. - International Journal of Cancer 2009.; 125: 1868-1875.

66. Spector, P. Data manipulation with R. Use R! 2008; New York, Springer:103.

67. Titus- Ernstof L., Perry A. E., Spencer S. K.,et al. Multiple primary melanoma:two year results from a population-based study. Arch Dermatol 2006; 142:433-8.

68. Zettersten E., Sagebiel R.W., Miller J.R. 3rd et al. Prognostic factors in primary cutaneous melanoma. Surgical Clinics of North America 2003; 83: 61-75. 


\section{SCIENTIFIC PUBLICATIONS}

1. Pjanova D, Azarjana K, Čēma I. Genetic alteration in melanoma development. Proc. Latvian Acad. Sci. Section B, 2009; 63(3): 73-81.

2. Pjanova D, Molven A, Akslen LA, Streinerte B, Engele L, Azarjana K, and Heisele O. Identification of a CDK4 R24H mutation-positive melanoma family by analysis of early-onset melanoma patients in Latvia. Melanoma Research, 2009; 19:119-122.

3. A. Ķempele, K. Azarjana, I. Čēma, D. Pjanova, A. Rivošs. Galvas un kakla lokalizācijas melanomas gadījumu raksturojums Latvijā. RSU Zinātniskie raksti, 2010; 1:313-319.

4. K. Azarjana, D. Pjanova, I. Čēma. Ādas ļaundabīgās melanomas jutības gēni. RSU Zinātniskie raksti, 2010; 2:175-182.

5. Berzina A, Azarjana K, Pjanova D, Cema I, Rivosh A. Prognostic factors and Epidemiological Characteristics of Cutaneous and Mucosal Head and Neck Melanoma. Stomatologija - Baltic Dental and Maxillofacial Journal, 2011; 2:49-54.

6. Azarjana K, Ozola A, Ruklisa D, Cema I, Rivosh A, Azaryan A, and Pjanova D. Melanoma epidemiology, prognosis, and trends in Latvia. Journal of European Association of Dermatology and Venereology. (Submitted: JEADV2012-0565). 


\section{PRESENTATIONS OF THE STUDY RESULTS}

\section{Oral presentations}

1. K. Azarjana, D.Pjanova, O.Heisele. Assessment of the nevus phenotype in melanoma kindreds from Latvia. GenoMEL Annual Meeting. Paris, France. 09.12.06.2008.

2. A. Ozola, K. Azarjana, L. Enğele, B. Štreinerte, I. Čēma un D. Pjanova. Melanokortīna 1. receptora gēna polimorfismi un melanoma. LU 68. Zinātniskā konference. Rīga, Latvija. 05.02.2010.

3. K. Azarjana, A. Ozola, O. Heisele, I. Cema, D. Pjanova. Susceptibility genes analyses in head and neck melanoma. 7th Congress of Baltic Association of Maxillofacial and Plastic Surgery. Riga, Latvia. 20-22.05.2010.

4. R. Veinalde, K. Azarjana, O. Heisele, D. Pjanova. p14/ARF promoter deletion in Latvian melanoma family. GenoMEL Annual Meeting. Tel Aviv, Israel. 03 05.10.2011.

5. K. Azarjana, R. Veinalde, O. Heisele, D. Pjanova. Identification of a third CDK4 R24H mutation positive melanoma family in Latvia. Perspectives in Melanoma XV. New York, USA. 16 - 17.09.2011.

\section{Theses}

1. D. Pjanova, O. Heisele, K. Azarjana, L. Enǵele, B. Štreinerte. Assessment of the nevus phenotype in CDK4 mutation positive melanoma kindreds from Latvia. 17th Congress of the European Academy of Dermatology and Venereology. Paris, France. 17-21.09.2008.

2. K. Azarjana, I. Čēma, L.Enğele, B. Štreinerte, O. Heisele, D. Pjanova. Cutaneous melanoma: epidemiological study. 3rd world meeting of interdisciplinary melanoma/skin cancer centers. Berlin, Germany. 19-21.11.2009.

3. K. Azarjana, I. Čēma, A. Kempele, A Rivosh, D. Pjanova. Cutaneous malignanat melanoma in Latvia - the study of Latvian Cancer registry data of incidence and mortality rates. 19th Congress of the European Academy of Dermatology and Venereology, Gothenburg, Sweden. 06.10. - 10.10.2010.

4. K. Azarjana, A. Ozola, D. Pjanova, I. Čēma, R. Kleina, L. Enǵele, B. Štreinerte un O. Heisele. $C D K N 2 A, C D K 4, M C 1 R$ gēnu izmaiņas melanomas pacientiem ar melanomas, aizkuṇga dziedzera vai smadzeṇu audzēja saslimšanas 
gadījumiem ğimenēs Latvijā. RSU 2010.g. Zinātniskā konference. Rīga, Latvija. 18.-19.03.2010.

5. A. Ķempele, K. Azarjana, I. Čēma, D. Pjanova: Galvas un kakla lokalizācijas primārās ādas melanomas prognostiskie faktori. RSU 2010.g. Zinātniskā konference. Rīga, Latvija.18.-19.03.2010.

6. R. Kleina, D. Pjanova, K. Azarjana, I. Čēma, O. Heisele. Dažādas lokalizācijas ādas melanomu morfometrisks novērtējums. RSU 2010.g. Zinātniskā konference. Rīga, Latvija. 18.-19.03.2010.

7. D. Pjanova, A. Ozola, K. Azarjana, O. Heisele, L. Engele, B. Streinerte, R. Kleina, I. Cema. $C D K N 2 A, C D K 4$, and $M C 1 R$ gene mutations in melanoma patients in Latvia. 5th Baltic Congress of Oncology, Riga, 14-15.05.2010.

8. A. Kempele, K. Azarjana, I. Cema, A. Rivosh, D. Pjanova. Cutaneous and mucosal head and neck melanoma: an apidemiological study. 6th Congress of European Association of Dermatologic Oncology. Athens, Greece. 16-19.06. 2010

9. D., Ozola A., Azarjana K., Donina S., Proboka G., Cema I., Heisele O., Streinerte B., Engele L.. MC1R gene polymorphisms increase the risk of cutaneous malignant melanoma in Latvia independently of skin type and hair color. 7th Congress of European Association of Dermato-Oncology. Nantes, France. 20-23.07.2011.

10. Azarjana K., Ozola A., Donina S., Proboka G., Cema I., Heisele O., Streinerte B., Engele L., and Pjanova D. MC1R gene polymorphisms and clinical and pathological features of melanoma in Latvia. 20th Congress of the European Academy of Dermatology and Venereology. Lisboa, Portugal. 20-24.10.2011. 